\title{
THE INFLUENCE OF FACTORS OF THE SOCIO-GEOGRAPHICAL STRUCTURE OF MOUNTAIN FARMS IN SLOVENIA UPON FARM SUCCESSION STATUSES AND DECISIONS VPLIV DEJAVNIKOV SOCIALNOGEOGRAFSKE STRUKTURE HRIBOVSKIH KMETII V SLOVENIJI NA STANJA IN ODLOCITVE GLEDE NASLEDITVE NA NJIH
}

Boštjan Kerbler - Kefo

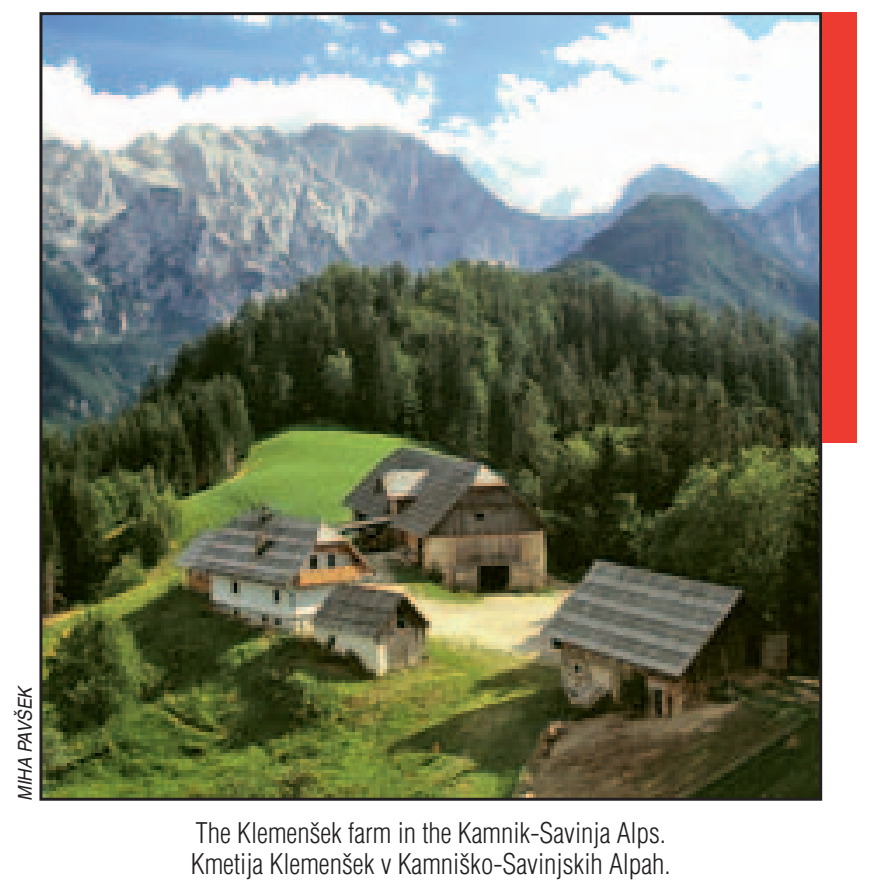




\title{
The influence of factors of the socio-geographical structure of mountain farms in Slovenia upon farm succession statuses and decisions
}

\author{
DOI: 10.3986.AGS48203 \\ UDC: $911.3(497.4): 631.111(23.01)$ \\ COBISS: 1.01
}

\begin{abstract}
This paper discusses the influence of single factors of the socio-geographical structure of mountain farms in Slovenia, independent of each other, as well as in conjunction with each other upon farm succession statuses and decisions. The methodology is described in detail, especially the discrete choice models by which these influences were assessed. The results were linked with findings from other researchers and show that the householder's perceptions about mountain farms, work and life on the farm, as well as tradition hold the most vital role with regard to succession on mountain farms. At the same time, in order to ensure succession and continuation of farming on the mountain farm, an appropriate economic basis must be assured.
\end{abstract}

KEY WORDS: social geography, agrarian geography, rural geography, agricultural economics, rural sociology, discrete choice models, mountain farms, farm succession.

The article was submitted for publication on September 13, 2007.

ADDRESS:

Boštjan Kerbler - Kefo, Ph. D.

Urban planning institute of the Republic of Slovenia

Trnovski pristan 2, SI - 1000 Ljubljana, Slovenia

E-mail: bostjan.kerbler@guest.arnes.si

\section{Contents}

1 Introduction 279

2 Terminology 280

2.1 Mountain farm 280

2.2 Farm succession status and decisions 280

3 Methodology 280

3.1 $\begin{aligned} & \text { Methods and determination } \\ & \text { of a dependent variable }\end{aligned}$
$\quad 280$

3.2 Determination of explanatory variables 281

3.3 Data source, determination of target group
and research sample

$4 \quad$ Results and discussion 282

4.1 Influence of individual factors of the socio-geographical structure of mountain farms

4.2 Influence of multiple factors of the socio-geographical structure of mountain farms at the same time $\quad 282$

5 Conclusion 290

6 References 291 


\section{Introduction}

According to Natek (1989) mountain farms are one of the most important and permanent preservers and creators of the cultural landscape in mountain areas. Their potential concentrates those landscape's elements, which with their various effects influence on changes in the landscape (Markeš 1998). Since farms are mainly the property of families (so-called 'family farms'), farm population is, according to Hribernik $(1994 \mathrm{a}, 32) » . .$. the only part of the society, which alone is assuring its socio-professional reproduction ...". "... Farm succession is therefore one of the key factors upon the reproductive capability of the farm and with this of its long-term existence... " (Kovačič 1996, 82). Farm succession should be influenced by various factors, "... thus it seems to be useful that they should be examined in detail ..." (ibid, 82).

While examining such influences, we focused our research on the inner factors, which characterize the farm respectively as they arise from the farm, and among them, on factors of the socio-geographical structure of the farm - factors of the population structure, the farm estate structure, the demo-geographical structure, the production (economic) structure, the technical and the developmental-innovative structure.

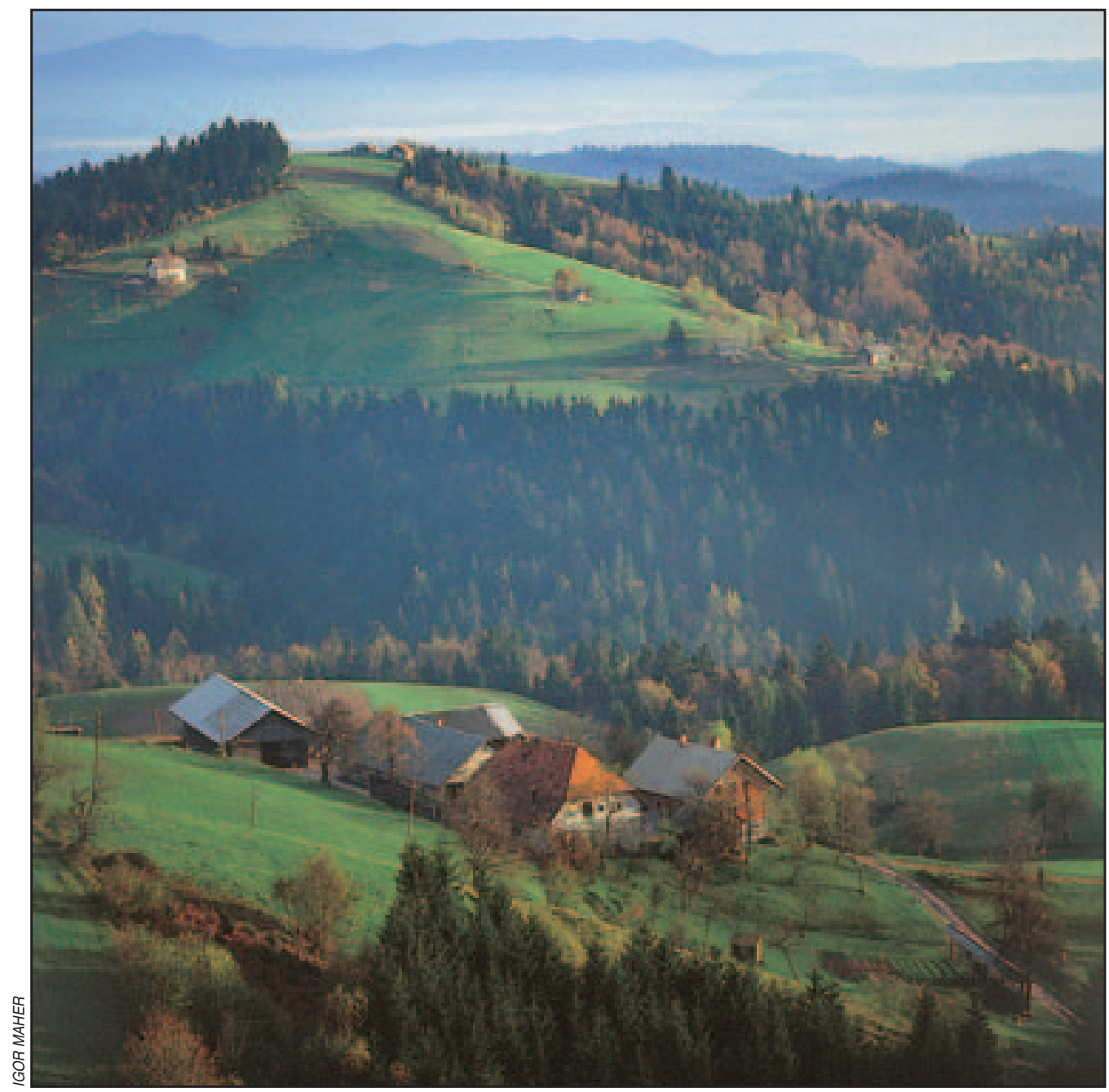

Figure 1: Mountain farms are an important element of the cultural landscape in mountain areas. 
The paper presents how these factors influence succession statuses and decisions on mountain farms, namely, what kind of influence has each factor separately, independent of each other, and what kind of influence these factors have when they happen in conjunction with each other.

\section{Terminology}

\subsection{Mountain farm}

With the intention of adjusting the research to data in used sources, mountain farms were defined on the basis of Robič's $(1988$; 1990) classification of less favoured areas for farming, namely as farms, which are situated in a mountain-altitude area above 600 meters above sea level, as well as farms, which lay under 600 meters, but have more than $60 \%$ of the agricultural land with slopes above $35 \%$ - according to Robič's typology, these are so-called 'steep farms'.

\subsection{Farm succession status and decisions}

In our research, farm succession status and decisions we defined as a hyponym of the term farm succession, which also includes the timing of the succession itself. Farm succession status means, whether such a person is appointed/expected as the farm successor, who is assured to take over the managerial control of the entire farm after the former householder vacates the premises and who will then become the householder and owner of the farm, but it is not necessary that such person is the householder's offspring (the research results have shown that $98.7 \%$ of successors are householder's descendants) and that he/she lives in the same household as the householder.

Farm succession decision means, whether this person has decided by his/her own to succeed the former householder, and whether this person has decided to continue farming after taking over the farm. In the research the term takeover is equate with the term succession, although according to Kladnik (1999) the takeover means to hand over a farm to manage it, but in comparison with succession, the changing of ownership is not necessary.

\section{Methodology}

\subsection{Methods and determination of a dependent variable}

Influences of the socio-geographical structure of mountain farms upon farm succession statuses and decisions were ascertained with help of discrete choice models - this expression was taken from Greene (2003), who designates these models also known as qualitative response (QR) models. These models are a form of regression models and are the opposite to the classical linear regression models (expression is taken from Gujarati (1995)), as they enable an insight into the causal relationship between response, dependent variable $\left(Y_{i}\right)$ and one or more explanatory, independent variables $\left(X_{1} \ldots X_{k}\right)$, even though the continuous, quantitative values are unknown, but only the final number of outcomes, which have discrete, qualitative values that have been distinguished (Bajt and Štiblar 2002; Juvančič 2002, taken from Maddala 1999; Wooldridge 2002).

According to Fox (1997) the typical property of regression models is that on the basis of the accepted model and the estimation of its parameters, the value of a dependent variable could be predicted from the values of explanatory variables; models of discrete choice - as probability models - enable forecasting response/choice probability (Liao 1994; Wooldridge 2002). Greene (2003) explains this with a formula:

Prob $($ event $j$ occurs $)=\operatorname{Prob}(Y=j)=P$ (relevant effects, parameters)

where Prob $(Y=j)$ means probability that an event $j$ will happen at an appointed $X_{i}$ and where the event is the individual's choice amongst the set of alternatives - outcomes of the dependent variable $Y_{i}$.

In the research two outcomes of dependent variable $Y_{i}$ were defined, namely as:

$Y_{i}=1$ a farm will be taken over by successor, who will continue farming;

$Y_{i}^{i}=0$ there will be no succession on a farm or the farm will be taken over by a successor, who will not continue farming. 
By this outcome of events, whether foreseen or planned - farm succession statuses and decisions are planned (foreseen). This approach of examining is called ex-ante (internet 1,2 ).

A probit model, termed also as a normit model was chosen as the starting methodological approach for the realisation of discrete choice models. Since the dependent variable has two outcomes, we talk of the so-called 'binary-choice/response probit model', respectively a 'dichotomous choice probit model'.

\subsection{Determination of explanatory variables}

Factors of the socio-geographical structure of mountain farms with an expected influence upon succession statuses and decisions on mountain farms in Slovenia were expressed in one or several different ways. The ways in which the factors of socio-geographical structure of farms were presented were determined as explanatory variables in a binary-choice probit model.

Each explanatory variable was coded with a corresponding symbol and presented by adequate measures. Explanatory variables were either qualitative or quantitative, and therefore the data were measured in different units. Following examples of other empirical analyses, with regard to the calculations of discrete choice models, explanatory variables were pondered by each other (and within themselves) and were therefore adequately modified or transformed. By this, one of the demands of realisation of regression analysis was fulfilled - the demand of homoscedasticity, which according to B. Košmelj and others (2001) means that in a regression model the variance of random errors or influences has to be constant for all observed values of explanatory variables, which are defined in advance.

\subsection{Data source, determination of target group and research sample}

Research data were acquired from a survey, carried out amongst the farm householders. In comparison to data of statistical services, a survey enables a detailed view into farm succession statuses and decisions as well as into the socio-geographical structure of farms themselves. Thus, we can obtain important data, which are not gathered by the statistical services. The survey was carried out using the postal service in June 2005.

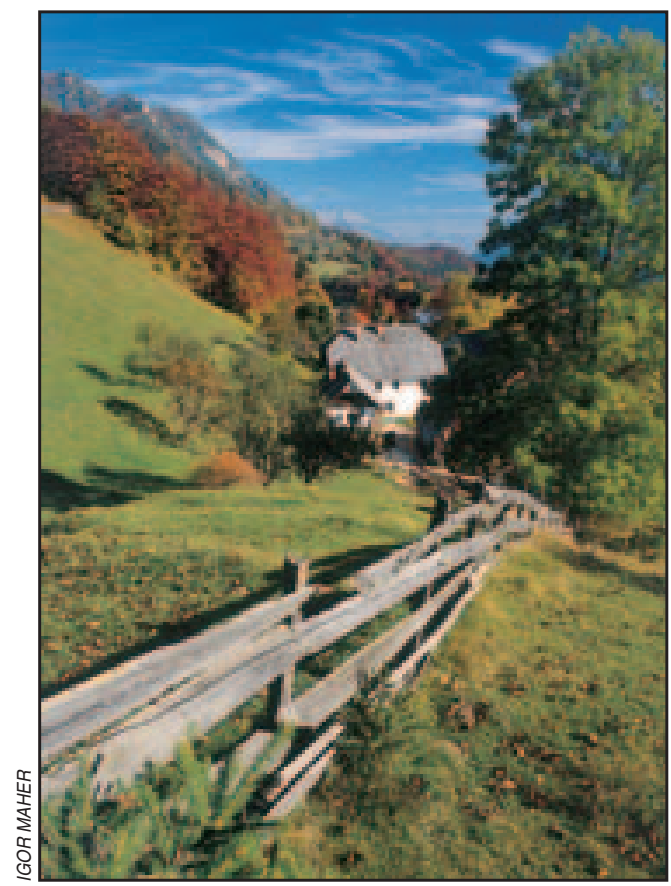

Figure 2: Seventy percent of all Slovene mountain farms (defined according to Robič's typology) are located in the Alpine and subalpine areas of Slovenia. 
In order to ensure a relevant comparability regarding the socio-geographical structure of individual mountain farms as possible, a homogeneous target group of mountain farms was created. The target group was defined under the following criteria:

- A farm had to be in the Alpine and subalpine areas of Slovenia, by which the area of alpine and subalpine regions of Slovenia was defined on the basis of Ilešič's physical-geographical regionalisation dating from 1972.

- The main production orientation on a farm was livestock-breeding - the breeding of grazing livestock or mixed livestock production.

- The farm householder's age was 45 or above.

On the basis of these three criteria and after the elimination of farms without data regarding the householder's age, 6801 mountain farms were chosen as the target group.

On the basis of the most recent data by the Statistical Register of farm households in Slovenia, in the year 2005, 3000 householders of mountain farms within the target group were randomly chosen. We further eliminated all the incomplete returned questionnaires. The final research sample contained 789 mountain farms respectively $11.6 \%$ of all mountain farms, which were defined as the target group on the basis of the set criteria.

\section{Results and discussion}

\subsection{Influence of individual factors of the socio-geographical structure of mountain farms}

Using a binary-choice probit model, we were assessing the influence of each explanatory variable $X_{i}$ on the dependent variable $Y_{i}$ where single factors with reference to the socio-geographical structure of farms were expressed by $X_{i}$. For factors of socio-geographical structure of farms, expressed by multiple explanatory variables, Table 1 shows the intensity and direction of influence of explanatory variable $X_{i}$, for which it was assessed to have greatest influence on dependent variable $Y_{i}$. The names and descriptions of the chosen explanatory variables are not quoted. The intensity of influences is determined by the $t$-value, while the direction of the influence of each factor refers to (if not stated otherwise) the favourable (positive) succession status and decisions on a farm and is determined with regard to the increase of the factor value, if it is quantitative; or with affirmation, if the factor is quantitative, where the only two possible answers are either 'yes' or 'no'. All influences of explanatory variables $X_{i}$ on dependent variable $Y_{i}$ presented for single factors in Table 1 are statistically significant at the least 90 percent confidence interval.

As we can see from Table 1, among factors of the socio-geographical structure, all factors of the population structure, the farm estate structure, the demo-geographical structure, the production (economic) structure and the developmental-innovative structure, for which influences were foreseen, influence upon farm succession statuses and decisions. The exceptions are the factors of the technical structure of the farm. This confirms Kovačič's (2001) statement that Slovene farms are over-mechanized and that the ownership of agricultural mechanization represents a status symbol.

\subsection{Influence of multiple factors of the socio-geographical structure of mountain farms at the same time}

Our intention was to find out how succession statuses and decisions on mountain farms are influenced by the greatest multitude of factors of the socio-geographical structure possible, but if the binary-choice probit model was to be as accurate as possible, they had to fulfil the following conditions in order to be included:

- The explanatory variable $X_{i}$, by which the factor was expressed, had to be defined for all farms.

- The influence intensity of the explanatory variable $X_{i}$, by which the factor was expressed, had to be distinctive. 
Table 1: Intensities and directions of estimated influences of the socio-geographical factors upon succession statuses and decisions on mountain farms in Slovenia.

Socio-geographical factor

Intensity and direction of influence

Factors of the population structure of a farm

Location of a farm (time/spatial remoteness of a farm and its position with regard

to natural factors). The intensity and direction of influence are determined,

if the location of a farm is not favourable with regard to natural factors.

Perception about the remoteness (isolation) of a farm. The intensity and direction of influence are determined, if the householder believes that farm is extremely remote from the main road in a valley and the closest administrative centres.

Factors of the demo-geographical structure of a farm

Number of persons on the farm

Number of children in the householder's family

Number of male children in the householder's family

Number of generations, which farm is in hands of the householder's family.

Householder's decision, whether he would decide to take over the farm and to run it,

if he had the opportunity to make this decision again.

Householder's age

Householder's gender (The intensity and direction of influence are determined, if the householder is male.)

Householder's succession from previous householder

Householder's married status, respectively unmarried status

Completed higher level of householder's general education

Householder's formal agricultural education

Householder's off-farm employment and/or off-farm employment of his/her partner

Successor's gender (The intensity and the direction of influence are determined, if successor is male.)

Successor's familial relationship to householder (The intensity and direction of influence are determined, if the successor is householder's son.)

Successor lives on householder's farm

Completed higher level of successor's general education respectively foreseen higher level of successor's general education at the end of his/her present schooling (The intensity and direction of influence are determined, if successor's general education is on the level of secondary school, separately (in parenthesis), however, if successor's education is higher or high.)

Successor's formal agricultural education

Successor's off-farm employment

Volume of labour input on the farm

Changes of volume of labour input on farm in the last ten years/in the future (The intensity and direction of influence are determined, if the volume of labour input on farm has increased in the last ten years or will increase in the future.)

Factors of the farm estate structure

Farm size

Perception about the farm size (The intensity and direction of influence are determined,

$++$

$++$ if the householder believes that his/her farm is big.)

Changes of the farm size in last ten years/in the future (The intensity and direction of influence are determined, if the farm size increased and/or will increase (i. e. area of the utilised agricultural land or the number of livestock).)

The area of agricultural land, which is not in use for agricultural production in relation to the total size of the farm.

Leasing of agricultural land on the farm/leasing out of agricultural land on the farm

Factors of the production (economic) structure of a farm

Marketing of the stockbreeding production

The intensity of stockbreeding

Quantity of annual removal of wood

Vitality of the forest's potential (The intensity and direction of influence are determined if householder believes that the forest is not cut out.)

Engagement in supplementary activities

Annual gross income derived from farm sources

Satisfaction with the amount of annual gross income derived from farm sources
$++$

$++$

$++++$

$++$

$+++$

$-$

$+$

$+$

$+$

$+$

$+$

$+$

$++$

$++$

$++$

$++(---)$

$++$

$--$

$+++$

$+++/+++$ 
Boštjan Kerbler - Kefo, The influence of factors of the socio-geographical structure of mountain farms in Slovenia ...

Socio-geographical factor

Intensity and direction of influence

The share of the income derived from farm sources/derived from off-farm sources in relation to the total annual gross income on the farm

The share of subsidies in relation to the total annual gross income

Types of income sources, from which annual gross income in last ten years has increased the most/which will prevail more in the future (The intensity and direction of influence are determined, if in the last ten years the annual gross income has increased mostly from farm sources and if this annual gross income will prevail on the farm in the future.)

Factors of the technical structure of a farm

Equippmency of farm with machines and devices 0

Equippmency of farm with machines and devices in the future $+++/---$ $+++$ $+++++++$

Factors of the developmental-innovative structure of the farm

Financial capability of the farm for investment in further developments

Debit of farm for further development owing to debt of rented loans and other financial loads

Engagement in ecological farming

Legend:

[++++] distinctive positive influence,

[+++] great positive influence,

[++] moderate positive influence,
[+] small positive influence,
[0] no influence;
[----] distinctive negative influence,

[---] great negative influence,

[--] moderate negative influence,

[-] small negative influence.

- Binary-choice probit models, by which influences of single explanatory variables on dependent variable $Y_{i}$ were examined, had to be reliable enough and they had to be very similar to the observed values they had to have a high explanatory value.

- Amongst the explanatory variables, which corresponded with the above demands, we further eliminated those, which expressed the highest colinearity with others. This is the occurrence, where the explanatory variables are closely connected to each other. Factors do not function in an isolated way; they change more or less together, in mutually connected way (Pfajfar 1998).

If factors were expressed with several explanatory variables, the eliminated variables were replaced with others, however with those where the outcomes of the dependent variable $Y_{i}$ could still be explained precisely enough. If a factor was expressed with one explanatory variable only, and if this explanatory variable was eliminated, the factor was eliminated too.

To the set demands (detailed description of explanatory variables is in Table 2), the following factors of the socio-demographical structure of farms or explanatory variables (with which we expressed them) corresponded:

- The householder's perception about the remoteness (isolation) - the factor of the population structure of a farm, expressed with the explanatory variable IZOL_LEG;

- The householder's decision whether to take over the farm, or not, if he/she had the possibility to make the decision again - the factor of the demo-geographical structure of a farm, expressed with the explanatory variable G_ODLOC;

- The number of male children in the householder's family - the factor of the demo-geographical structure of a farm, expressed with the explanatory variable OTRM_OTR;

- Agricultural land, which is not in use for agricultural production. With this factor the (actual) farm size is indirectly expressed (due to the moderate intensity of influence and colinearity area of utilised agricultural land (KZU) respectively number of livestock (LSU), which are the most important indicators and expresses the farm size, have not been included into model).

- the factor of the farm estate structure, expressed with the explanatory variable KZZO_KZU; although it would be more logical to include explanatory variable, which expresses relation among total area of leased out agricultural land, the overgrown agricultural land and uncultivated agricultural land and the owned area of the agricultural land (KZdNZO_KZL) into the model, this explanatory variable was replaced by the explanatory variable KZZO_KZU, due to colinearity.;

- The marketing of stockbreeding production - the factors of the production (economic) structure of a farm, expressed with the explanatory variable ZIV_PROD; 
- Annual gross income derived from farm sources (Since no tested farm keeps the evidence of changeable and fixed expenses, it was decided to collect data of gross income instead of net income with survey.) the factors of the production (economic) structure of a farm, expressed with the explanatory variable PR_EUR;

- Types of income sources, which will prevail on a farm in the future - the factors of the production (economic) structure of a farm, expressed with the explanatory variable PR_F_POV.

Table 2: Symbols and descriptions of explanatory variables, used in the realisation of binary-choice probit model.

\begin{tabular}{|c|c|}
\hline Symbol & Description \\
\hline IZOL_LEG & $\begin{array}{l}\text { Householder's opinion about the remoteness or the isolation of the farm from the closest administrative centres and the } \\
\text { main road in the valley (dummy variable). As a dummy variable we denominate a variable which is adapted to each value } \\
\text { of the nominal variable and receives the value of } 1 \text { if the unit has the selected value of the nominal variable and a value } \\
\text { of } 0 \text { if the unit does not have the selected value of the nominal variable (B. Košmelj and others 2001). }-1=\text { yes, } 0=\text { no) }\end{array}$ \\
\hline G_ODLOC & $\begin{array}{l}\text { Householder's decision whether he would decide to take over the farm and to run it, if he had another chance to decide } \\
\text { (dummy variable }-1=\text { yes, } 0=\text { no). }\end{array}$ \\
\hline OTRM_OTR & The ratio of male children and the total number of children in the householder's family (coefficient) \\
\hline KZZO_KZU & $\begin{array}{l}\text { The ratio between the total area of overgrown and uncultivated agricultural land and the area of utilized agricultural land } \\
\text { (coefficient) }\end{array}$ \\
\hline ZIV_PROD & The amount of livestock-breeding production for sale (modified value - 1 = 100 percent) \\
\hline PR_EVR & $\begin{array}{l}\text { The estimation of the annual gross income derived from farm sources (dummy variable }-0=\text { up to } 2,086.46 \text { euros } \\
(500,000 \text { tolars), } 1=\text { above } 2,086.46 \text { euros }(500,000 \text { tolars)). }\end{array}$ \\
\hline PR_F_POV & $\begin{array}{l}\text { Types of income sources, which will prevail on the farm in the future, according to householder's opinion (dummy } \\
\text { variable }-1=\text { farm sources, } 0 \text { = off-farm sources). }\end{array}$ \\
\hline
\end{tabular}

Since we are dealing with discrete choice models, the prediction accuracy of our calculated model, presented in Table 3 is quite high - the value of the dependent variable $Y_{i}$ estimated with the model, corresponds well with the observed (actual) values. Model correctly predicts $78.3 \%$ of all outcomes of the dependent variable $Y_{i}$, however the value of McFadden's $R^{2}$ respectively LRI is 0.314 . According to Juvančič (2002, by Huffman 1991) LRI values about 0.3 could already be estimated as high; however, logical results would be also obtained by models with lower values. The least significant is the influence with reference to the factor defined as the annual gross income derived from farm sources (PR_EUR). This is also the only factor, which is statistically significant at 90 percent confidence interval, while other factors are significant at less than 5 percent or less than 1 percent risk.

Table 3 contains also the values of marginal effects. They show how much the value of the dependent variable $Y_{i}$ changes, if the value of the explanatory variable $X_{i}$ changes for one unit, upon the assumption that the values of other explanatory variables would remain unchanged or constant - the so-called assumption ceteris paribus (all other factors remaining unchanged). The estimated values of the marginal effects are based upon the average values of explanatory variables. Therefore we can talk about the influence of the explanatory variables on a hypothetical/potential average farm (Gujarati 1995; Juvančič 2002; Wooldridge 2002; internet 3).

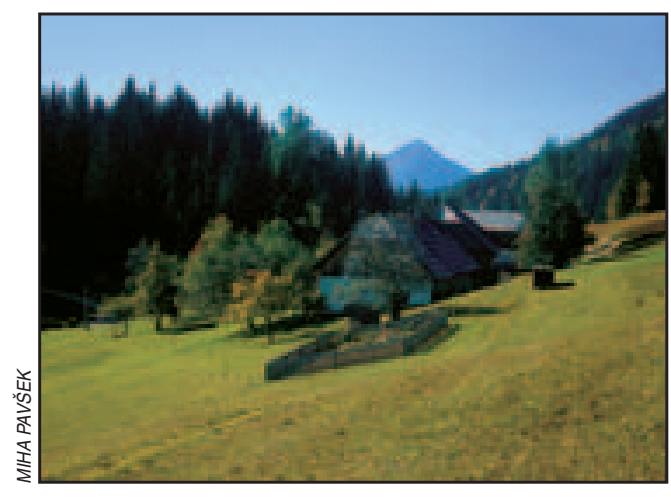

Figure 3: Farm succession is more threatened on peripheral mountain farms than it is on farms, which are closer to administrative centres, various sorts of service activities and major transport routes. 
The influence of the householder's perception regarding the location of a mountain farm (IZOL_LEG) on farm succession statuses and decisions is negative. If the householder of a hypothetical farm believes that his/her farm is remote, distant from the closest administrative centres and main roads in a valley, the probability that there will be no succession on that farm or that the farm will be taken over by a successor, who will not continue farming is (at assumption ceteris paribus) 10.9\% lower than it would be, if the householder thinks the opposite. The householder's subjective perception about the remoteness (isolation) of his/her farm has an important motivation effect regarding the preparation and decisions of the appointed or expected successor for the takeover of the farm. On the basis of Neldert et al. (1981) findings Tietje (2004) quoted that the orientation of parents is often transferred to their children. Detailed analysis of the results shows that the influence of this factor is connected with better conditions and possibilities for off-farm employment (also in better paid jobs), with the possibility of combining different incomes, as well as with the assurance of the standard of living, comparable to the standard of those who work in other spheres and with other forms of more accessible and developed social infrastructures. The succession and the continuation of farming practices will take place on more than $85 \%$ of farms, where householders do not perceive a spatial and time remoteness of their farms. However, on these farms, the appointed or expected successors will also be employed off-farm in the future. This (succession and continuation of farming) will happen on $43 \%$ of farms, where the appointed or expected successors will also be employed off-farm in the future, but where the householders connects their farms to a spatial and time remoteness. Despite personal motorization, the physical and psychical burden is intensified with commuting on a daily basis, due to the remoteness of farms in relation to the location of householders' employment in non-agricultural fields of work.

Table 3: Results of realisation of binary-choice probit model with more explanatory variables.

\begin{tabular}{lcccc}
\hline Explanatory variable & Coefficient & T-value & Significance level & Marginal effects \\
\hline Constant & -0.537 & -3.192 & 0.001 & \\
IZOL_LEG & -0.293 & -2.454 & 0.014 & -0.109 \\
G_ODLOC & 0.395 & 3.057 & 0.002 & 0.149 \\
OTRM_OTR & 0.386 & 2.436 & 0.015 & 0.015 \\
KZZO_KZU & -0.117 & -2.247 & 0.025 & -0.004 \\
ZIV_PROD & 0.541 & 2.345 & 0.019 & 0.004 \\
PR_EUR & 0.261 & 1.672 & 0.094 & 0.099 \\
PR_F_POV & 0.345 & 2.648 & 0.008 & 0.130 \\
\hline
\end{tabular}

Number of farms $-\mathrm{N}: 789$

Log-likelihood function - $\log L:-395.00$

Restricted $\left(\beta_{i}=0\right) \log$-likelihood function $-\mathrm{R} \log \mathrm{L}:-527.77$

Likelihood ratio test - LRT - (degree of freedom): $265.54(7)^{\star \star * *}$

McFadden's pseudo- $R^{2}$ - respectively likelihood ratio index - LRI: 0.314

Adjusted McFadden's pseudo- $R^{2}: 0.307$

Akaike information criterion - AIC: 1.046

Share of correctly predicted outcomes of dependent variable $Y_{\text {- }}$-count $R^{2}: 78.3 \%$

Share of correctly predicted outcomes $Y_{i}=1\left(Y_{i}=0\right): 67.2 \%(85.4 \%)$

*** Model is statistically significant at less than 1 percent risk.

According to Fasterding (1995; 1999) and Tietje (2004) the householder's decision that he would again take over the farm and run it, if he had that chance (G_ODLOC), also has an important motivational effect, since it expresses the householder's satisfaction with the job he attends. If the householder of a hypothetical farm decided to take over the farm again, the probability (at assumption ceteris paribus) that he will be succeeded by a successor, who will continue farming, is 68.4 percent, but if he did not decide to take over the farm, the probability for the realisation of the event $Y_{i}=1$ is reduced by $14.8 \%$. Furthermore, the more detailed empirical analysis of the results shows that the influence of this factor on farm succession statuses and decisions is greater, if a successor lives on the farm all the time, as he gains knowledge during the socialization period, where he allows himself an accurate insight into the householder's work and farm life-style on a general level; he acquires direct experiences and intergenerational transferred knowledge, but at the same time he forms through positive householder's attitude a respectful relationship, especially 


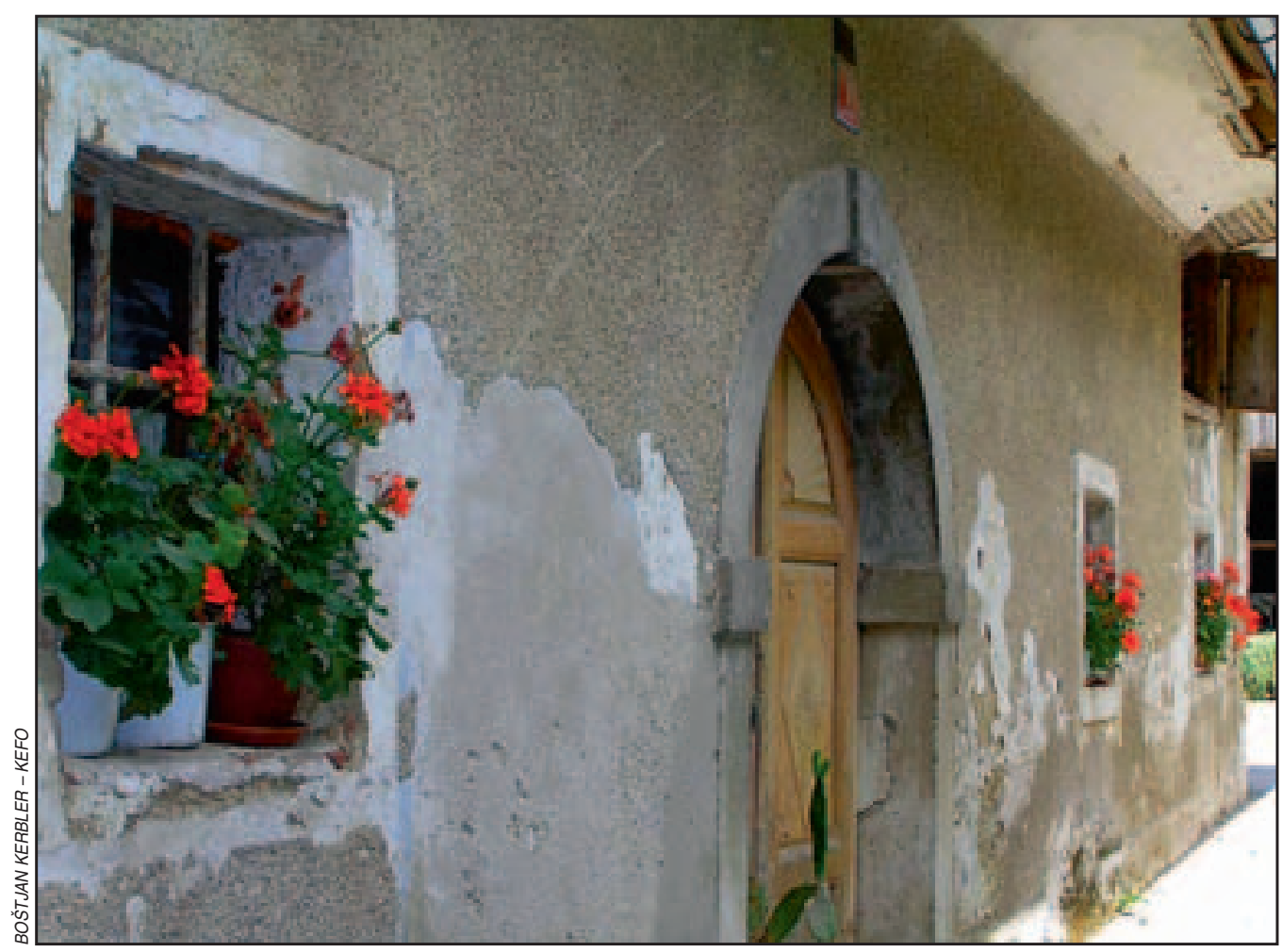

Figure 4: Due to devotion to tradition, the level of abandoning agricultural activity is less than would be expected, given the marginal status of the agricultural occupation in Slovene society.

with the land as the primary source of survival on the farm. According to Hribernik (1993), tradition is still a very powerful factor for the persistency in farming, even for younger generations.

As it is ascertained by Kimhi and Nachlieli (2001), householder's sons have traditionally an advantage over the daughters. According to Hribernik (1994b), the behavioural patterns are preserved very well during the transfer of the farm to a successor. This is confirmed with the positive influence of the number of male children in the householder's family (OTRM_OTR) on farm succession statuses and decisions. If on a hypothetical, average farm all the householder's children are male, the probability (at assumption ceteris paribus) that the farm will be taken over by a successor, who will continue farming, is almost at 70 percent. If half of the householder's children are male and half female, the probability (at assumption ceteris paribus) that the event $Y_{i}=1$ will happen, is 62.9 percent; but if the householder has only female descendants the probability is down to 55.2 percent. More detailed analysis shows that daughters are usually chosen by the householder to takeover the farm only because of the absence of any male offspring - in almost $65 \%$ of examined farms, where the householder's daughters were chosen to takeover the farm, there were no male descendants. At the same time, daughters are usually expected only to take over the farm - the percentage of successors, chosen in this way is 84.6 - and they are not appointed for sure. From this we can conclude that some householders still hope to appoint a male successor. Such traditional pattern of acting and thinking poses a grave threat to the existence of farms - it obstructs the succession process and (timely) transfer of farms to successors, however, we believe that it is not important for the successor to be only of the male gender.

The marketing of stockbreeding production (ZIV_PROD) is the factor of the economic structure of a farm, but it also expresses the developmental orientation. For market production, farmers have to adjust the agricultural production to market demands and they have to produce goods, which are in demand and which are of the appropriate quality. Since according to Vrišer (1995), dynamic and younger people 
manage the best in such circumstances, we concluded that the decision to take over the farm and continue farming plays an incentive role for the potential successor. This is confirmed by the results of the model. If on a hypothetical average farm, the market share of livestock-breeding production increases by $1 \%$, the probability (at assumption ceteris paribus) that the farm will be taken over by a successor, who will continue farming, increases by $0.4 \%$. If the market share of livestock-breeding production is 50 percent, with the same assumption, the probability of realisation of event $Y_{i}=1$ amounts to $61.4 \%$, but if this market share is 100 percent, the probability is $70.5 \%$. If a hypothetical average farm doesn't sell products from livestock-breeding production, the probability (at assumption ceteris paribus) that the farm will be taken over by a successor, who will continue farming is 51.2 percent. The more detailed results of the empirical analysis also show that on farms with low market share of livestock-breeding production, especially those with elder householders, often persist with farming and that these householders expect the same from their successors - almost $60 \%$ of householders above the age of 65 have already appointed or expected their successors; nevertheless these appointed or expected successors will not decide to take the farm over or they will not continue farming. For many householders, especially for those elderly ones, farming means preserving traditions, styles, the meaning of life - a life project - but not capital, which has to be perpetually refined. At the same time, they are emotionally attached to their farms and the environment that they inhabit.

The annual gross income derived from farm sources (PR_EVR) also has a positive impact on farm succession statuses and decisions. If on a hypothetical average farm, the annual gross income derived from farm sources is lower then 2,086.46 euros or half of million tolars, the probability (at assumption ceteris paribus) that the householder will be succeed by a successor, who will continue farming, amounts to almost 56\%. If the income is higher, the probability of the realisation of event $Y_{i}=1$ with the same assumption will increase to almost 66 percent. As the survey had been carried out before the euro became the new currency in Slovenia, the estimates of the annual gross income are also quoted in tolars. Although the influence of this factor is less reliable, the detailed empirical analysis of the data of the examined farms

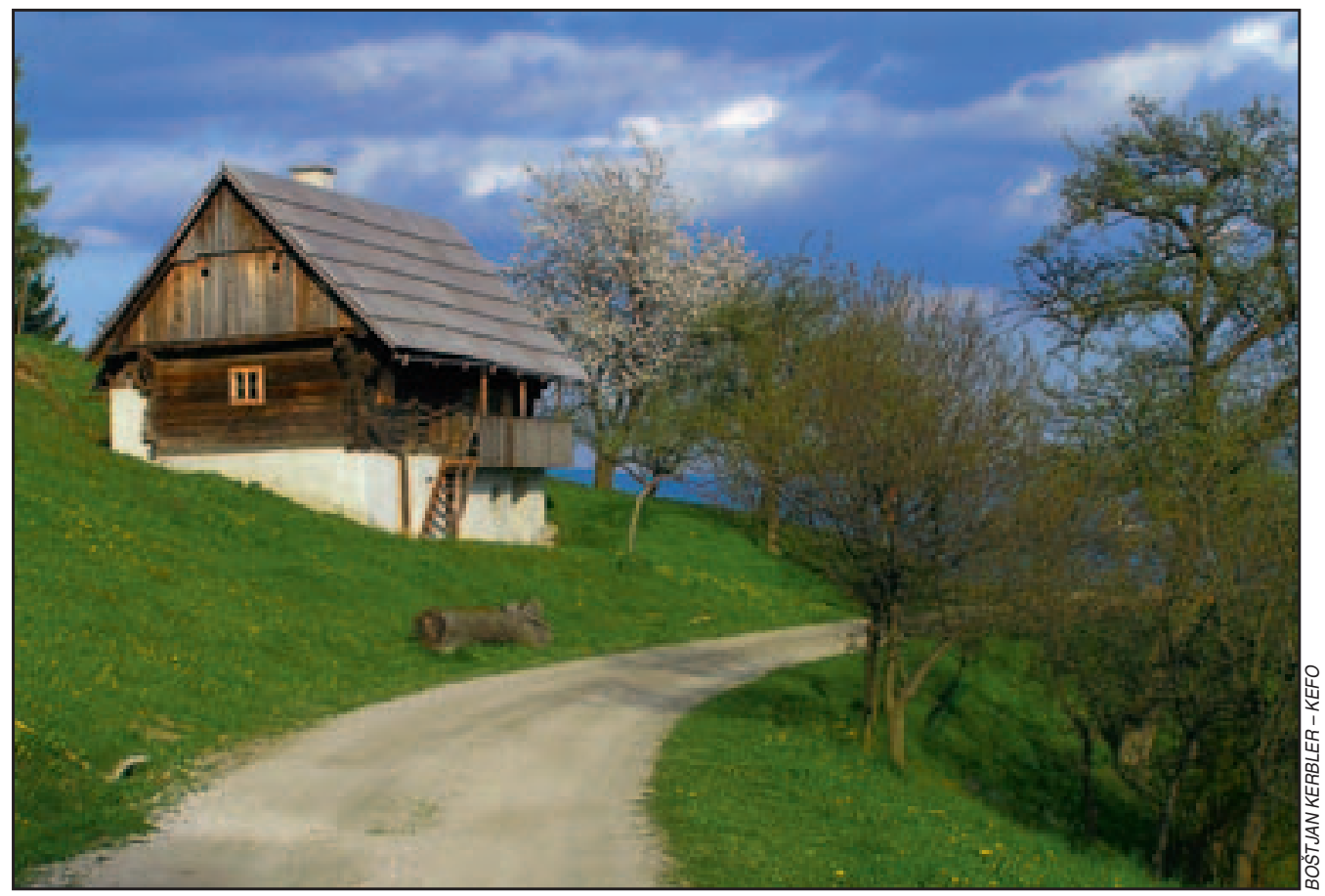

Figure 5: As the farm is taken over by a successor, farm development is strengthened - we can talk about successor effect or new blood effect. According to Blanc and Perrier-Cornet (1993), young householders are the driving force of modernisation of farm structures. 
shows additional findings regarding the impact of this factor. If the annual gross income derived from farm sources amounts to 4,172.93 euros or one million tolars, the percentage of farms where no succession will appear or the successor will not continue farming after the takeover is much higher (62 percent) than on farms with higher annual gross income derived from farm sources ( 21 percent). Of these (first mentioned) farms the majority of householders and/or their spouses acquire their gross income from off-farm sources and also almost all appointed or expected successors intend to be employed off-farm in the future. More than $60 \%$ of them will not decide to take over the farm or will not continue with farming after the expected takeover. However, on farms, where according to the estimation of respondents, the annual gross income derived from farm sources amounts to 12,518.78 euros or three million tolars, almost $85 \%$ of the appointed and expected successors, who plan to be employed off-farm in the future, will take over the farms and continue farming - therefore, they will combine the gross income derived from farm sources and from off-farm sources. On average, on these farms the gross income derived from farm sources represents more than $44 \%$ of the total annual gross income. These characteristics confirm our findings, presented in discussion regarding the marketing of livestock-breeding production, as well as findings of A. Barbič $(1993,265)$, that »... young people, who persist in agriculture, do this less and less from emotional and more and more from economic reasons... «; as well as Hribernik's $(1996,28)$ finding, that »... only farms, which will create enough income, will survive, which however means searching of income on essentially wider basis...«.

R. Gasson (1986) ascertains that off-farm employment, which usually contributes the most to the total share of income from off-farm sources, also contributes to greater stability and to an increase in the total farm income, and with this to the profitability and the continuation of farming itself. But at the same time it could be the first step to the cessation and abandonment of farming, especially if these sources start prevailing with regard to the total annual income on the farm. Regarding the types of income sources, which will prevail on the farm in the future (PR_F_POV) we assessed that the influence of this factor on farm succession statuses and decisions is a positive one, if income from farm sources will prevail on the farm in the future. The probability that the farm will be taken over by a successor, who will also continue farming, is on a hypothetical average farm and at assumption ceteris paribus $70.5 \%$, but if on the same farm and with the same assumption, the off-farm income will prevail, this probability is down to 57.5 percent or 13\% lower. The results confirm the findings about the role of householder's satisfaction with the work on the farm. We can conclude that the potential successors on farms with a strong attachment to the work and life are more motivated to takeover the farm, which then leads to a continuation of farming. This is also confirmed with the finding that on farms, where farm sources represent more than a half of the total annual gross income, almost $60 \%$ of householders would decide to takeover the farm again, whereas on farms, where more than half of the total annual gross income is represented by off-farm sources, the majority of them would not decide for the takeover.

Owned agricultural land, which is not in use for agricultural production (KZZO_KZU) influences positively on succession statuses and decisions - the probability that the farm will be taken over by a successor, who will continue farming is decreasing, if the total area of overgrown and uncultivated agricultural land is increasing in comparison with the total size of the agricultural land in use. If on a hypothetical average farm, the agricultural land is not overgrown or is not uncultivated - therefore all agricultural land (owned or eventually leased) is in use - the probability (at assumption ceteris paribus) that the farm will be taken over by a successor, who will also continue farming amounts to $65.5 \%$. The probability decreases by $4.5 \%$, if on such a farm, the area of utilized agricultural land is equal to the area of overgrown and uncultivated agricultural land; but if on a farm, where the area of overgrown and uncultivated agricultural land is three times larger than the total area of utilized land, the probability of the realisation of event $Y_{i}=1$ at assumption ceteris paribus decreases to $51.6 \%$.

These results raise an important dilemma, namely, whether the use of the agricultural land is the cause for this situation and the decisions regarding succession or is its consequence. Potter and Lobely (1992) interpret it as a consequence, and base their interpretation on the assumption that the expectation of farm succession affects the householder's behaviour and also decisions. In discussions from 1992, 1996a and 1996b, the authors talk about the so-called 'succession effect', by which the expectation of the farm succession should motivate the householders toward the systematic investing into farm development and for the optimal use of all agricultural land; whereas on the farms, where the succession is not expected, the area of utilized agricultural land is expected to diminish. As a solution for understanding these causes and effects, 


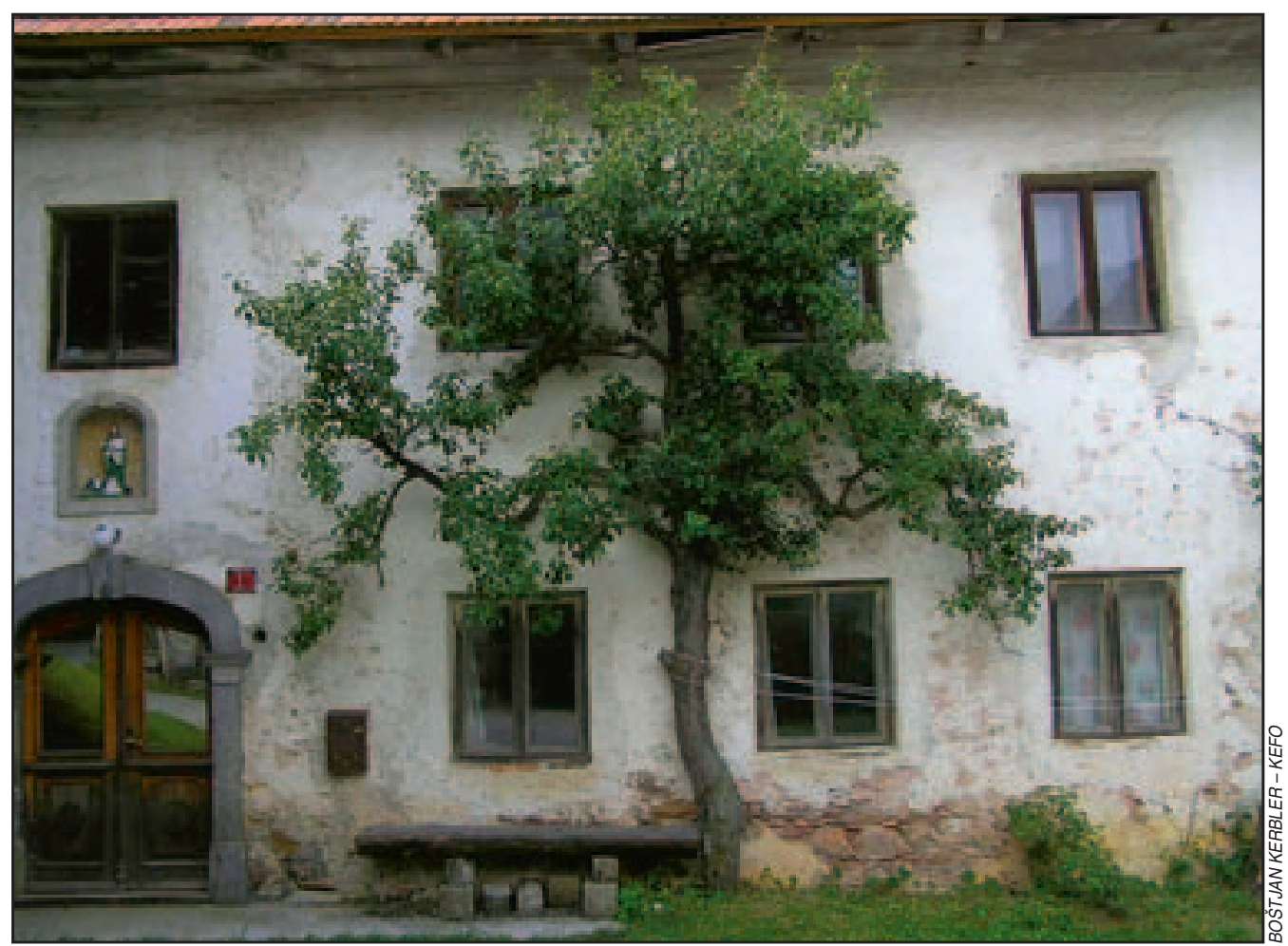

Figure 6: On farms without successors the amount of working hours, area of utilised agricultural land and total amount of agricultural production are gradually reduced after the householder's retirement. Machines, farm mechanisation and buildings, which often become abandoned, are less maintained - signaling the approaching of the shadow of death effect.

Stiglbauer and Weiss (2000), Kimhi and Nachlieli (2001) as well as Glauben and others (2004) suggested a broader time frame of observation, but the research itself should be concentrated on the examination of the 'family cycle' of each farm separately.

\section{Conclusion}

Research showed that succession statuses and decisions on mountain farms are influenced by the factors of the population structure, the farm estate structure, the demo-geographical structure, the production (economic) and the developmental-innovative structure of the farm, but they are not influenced by factors of the technical structure. The most influential are those factors, which express how householders comprehend their farms, their structure, work and life on the farm itself. This shows that the socialization process and the respect of traditional values still play a very important role in the succession process on mountain farms. Nevertheless, the joy of work and life on mountains farms and traditions are only a preliminary condition for the potential successors' decision as to whether to take over the farm and continue farming. They base their decision upon whether the total annual amount of gross income derived from farm sources is appropriate, and whether the farm has a potential for investment toward further development. Another big influence is the amount of subsidies granted in respect to their share in the total annual gross income on the farm. If this condition is not fulfilled, the factors with a negative influence on succession statuses and decisions on mountain farms come to the fore (e.g. the increasing remoteness of the farm from employment centres, where appointed and expected successors could find employment after the takeover of the farm, the dominance of the off-farm sources in the structure in relation to the 
total gross income, the successor's off-farm employment, the successor's higher or high level of general (non-agricultural) education). These factors begin to prevail gradually and persistence with the traditional patterns of acting and thinking may begin to threaten the further development and existence of farms. Also important is the realization that each farm is unique and for this reason the same holds for the succession process. In order to understand the casual-consecutive relations with regard to the succession on mountain farms, further research should focus on the identification of the life cycle of each individual farm.

\section{References}

Bajt, A., Štiblar, F. 2002: Statistika za družboslovce. Ljubljana.

Barbič, A. 1993: (Samo)obnavljanje kmečkega sloja v Sloveniji. Sodobno kmetijstvo 26-6. Ljubljana.

Blanc, M., Perrier-Cornet, P. 1993: Farm Transfer and Family Entry in the European community. Sociologia Ruralis, 33-3-4. Oxford.

Fasterding, F. 1995: Hofnachfolge in Westdeutschland. Landbauforschung Völkenrode 45-1. Braunschweig. Fasterding, F. 1999: Nachfolge in ladwirtschaftlichen Betrieben in Deutschland. Berichte über Landwirtschaft 77-2. Berlin.

Fox, J. 1997: Applied regression analysis, liner models, and related methods. London, New Delhi.

Gasson, R. 1986: Part time farming: Strategy for survival? Sociologia ruralis 24-3. Oxford.

Glauben, T., Tietje, H., Weiss, C. H. 2002: Intergenerational Succession on Farmily Farms: Evidence from Survey Data. Internet: http://www.food-econ.uni-kiel.de/Workingpaper/Ewp0202.pdf (12.9. 2003).

Glauben, T., Tietje, H., Weiss, C. H. 2004: Succession in Agriculture: A Probit and Competing Risk Analysis. Internet: http://www.food-econ.uni-kiel.de/Workingpaper/FE0406.pdf (7.7.2004).

Greene, W. H. 2003: Econometric analysis. New Jersey.

Gujarati, D. N. 1995: Basic econometrics. New York.

Hribernik, F. 1993: Vpliv vrednotenja izobraževanja in vrednotenja poklicev na šolanje kmečke mladine. Sodobno kmetijstvo 26-6. Ljubljana.

Hribernik, F. 1994a: Proces zapuščanja kmetijstva se nadaljuje. IB revija 28-3-4. Ljubljana.

Hribernik, F. 1994b: Sklepanje in razveljavljanje zakonskih zvez v Sloveniji s posebnim ozirom na kmečko prebivalstvo. IB revija 28-12. Ljubljana.

Hribernik, F. 1996: Ali lahko kmetije v Sloveniji zagotavljajo primerno socialno varnost kmečkemu prebivalstvu? Socialno delo 35-1. Ljubljana.

Ilešič, S. 1972: Slovenske pokrajine. Geografska regionalizacija Slovenije. Geografski vestnik 44. Ljubljana. Internet 1: http://economics.about.com/cs/economicsglossary/g/ex_ante.htm (27.8.2006).

Internet 2: http://economics.about.com/library/glossary/bldef-ex-post.htm (27.8.2006).

Internet 3: http://www.nd.edu/ rwilliam/xsoc694/x07.pdf (7.6.2006).

Juvančič, L. 2002: Model odločanja o zaposlovanju na kmečkih gospodarstvih v Sloveniji. Doktorska disertacija. Univerza v Ljubljani, Biotehniška fakulteta. Ljubljana.

Kerbler, B. 2002: Geografske značilnosti hribovskih kmetijskih gospodarstev v občini Ribnica na Pohorju. Diplomsko delo. Univerza v Ljubljani, Filozofska fakulteta. Ljubljana.

Kimhi, A., Nachlieli, N. 2001: Intergenerational Succession on Israeli Family Farms. Journal of Agricultural Economics 52-2. Oxford.

Košmelj, B., Arh, F., Doberšek Urbanc, A., Ferligoj, A., Omladič, M. 2001: Statistični terminološki slovar. Ljubljana.

Kovačič, M. 1996: Socio-ekonomska in velikostna struktura kmetij v Sloveniji v obdobju 1981-1991. Ljubljana.

Kovačič, M. 2001: Podjetniške in sociološke značilnosti kmetij v Sloveniji. Internet: http://www.bf.uni-lj.si/ daes/index_files/DS-1-kovacic.pdf (11.4.2007)

Liao, T. F. 1994: Interpreting probability models: logit, probit, and other generalized linear models. London, New Delhi.

Markeš, M. 1998: Vloga kmetijstva v razvojnem programu Triglavskega narodnega parka. Kmetijstvo in okolje: zbornik posveta. Ljubljana. 
Natek, M. 1989: Kmetije kot činitelji in jedra gospodarske in socialne preobrazbe hribovskega sveta. Dela 6. Ljubljana.

Neldert, L., Pieper, I., Kappus, W. 1981: Berufswünsche und vorstellungen von Jugendlichen aus landwirtschaftlichen Familien unter besonderer Berücksichtigung der Situationen von Hofnachfolgern. Göttingen.

Pfajfar, L. 1998: Ekonometrija - 1. Ljubljana.

Pfeffer, M. 1989: Part-time farming and the stability of family farms in the Federal Repubilc of Germany. European Review of Agricultural Economics 16. Oxford.

Potter, C., Lobley, M. 1992: Ageing and Succession on Family Farms: The Impact on Decision-making and Land Use. Sociologia Ruralis, 32-2-3. Oxford.

Potter, C., Lobley, M. 1996a: Unbroken Threads? Succession and its Effects on Family Farms in Britain. Sociologia Ruralis 36-3. Oxford.

Potter, C., Lobley, M. 1996b: The Farm Family Life Cycle, Succession Paths and Environmental Change in Britain's Countryside. Journal of Agricultural Economics 47-2. Oxford.

Robič, T. 1988: Razvojni cilji kmetijsko nerazvitih območij. Kmetijski priročnik 1989. Ljubljana.

Robič, T. 1990: Območja z omejenimi naravnimi dejavniki za kmetijstvo v SR Sloveniji. Ljubljana.

Stiglbauer, A., M., Weiss, C., R. 2000: Family and Non-family Succession in Upper-Austrian Farm Sector. Cahiers s'economie et sociologie rurales 54. Ivry.

Tietje, H. 2004: Hofnachfolge in Schleswig-Holstein. Doktorska disertacija, Institut für Ehnärungswirtschaft und Verbrauchslehre der Christian-Albrechts-Universität zu Kiel, Kiel. Internet: http://e-diss.uni-kiel.de/ diss_1277/d1277.pdf (22.4.2005).

Väre, M., Weiss, C.H. 2003: Farmers' succession considerations and realization of succession plans. Internet: http://www.mm.helsinki.fi/ hsmakine/nova/Vare.pdf (24.2.2004).

Vrišer, I. 1995: Agrarna geografija. Ljubljana.

Wooldridge, J. M. 2002: Econometric analysis of cross section and panel data. Cambridge, London. 



\title{
Vpliv dejavnikov socialnogeografske strukture hribovskih kmetij v Sloveniji na stanja in odločitve glede nasleditve na njih
}

\author{
DOI: 10.3986.AGS48203 \\ UDK: 911.3(497.4):631.111(23.01) \\ COBISS: 1.01
}

IZVLEČEK: V prispevku je predstavljeno, kako vplivajo na stanja in odločitve glede nasleditve na hribovskih kmetijah v Sloveniji posamezni dejavniki socialnogeografske strukture teh kmetij, torej neodvisno drug od drugega, in kako vpliva več teh dejavnikov hkrati. Podrobneje je opisana metodologija dela, zlasti modeli diskretne izbire, $\mathrm{s}$ katerimi smo vplive ugotavljali, spoznanja o vplivih pa so povezana $\mathrm{z}$ ugotovitvami slovenskih in tujih raziskovalcev. Rezultati kažejo, da imata pri nasleditvah na hribovskih kmetijah najpomembnejšo vlogo gospodarjeva percepcija o hribovski kmetiji, delu in življenju na njej ter tradicija, sočasno z njima pa mora biti zato, da bo na njej do nasleditve in nadaljnjega kmetovanja prišlo, zagotovljena tudi primerna ekonomska osnova.

KLJUČNE BESEDE: socialna geografija, agrarna geografija, geografija podeželja, agrarna ekonomika, ruralna sociologija, modeli diskretne izbire, hribovske kmetije, nasledstvo na kmetijah.

Uredništvo je prejelo prispevek 13. septembra 2007.

NASLOV:

Boštjan Kerbler - Kefo, dr.

Urbanistični inštitut Republike Slovenije

Trnovski pristan 2, SI - 1000 Ljubljana, Slovenija

E-pošta: bostjan.kerbler@guest.arnes.si

\section{Vsebina}

1 Uvod 295

2 Terminologija 295

2.1 Hribovska kmetija 295

2.2 Stanje in odločitve glede nasleditve na kmetiji 295

3 Metodologija 295

3.1 Metode dela in opredelitev odvisne spremenljivke 295

3.2 Opredelitev pojasnjevalnih spremenljivk 296

3.3 Podatkovni vir in opredelitev ciljne skupine
ter raziskovalnega vzorca

$4 \quad$ Rezultati in razprava 297

4.1 Vplivi posameznih dejavnikov socialnogeografske strukture hribovskih kmetij 297

4.2 Vplivi več dejavnikov socialnogeografske strukture hribovskih kmetij hkrati 297

5 Sklep 303

6 Literatura 303 


\section{Uvod}

Hribovske kmetije so po Natku (1989) eden od najpomembnejših in trajnih vzdrževalcev ter oblikovalcev hribovske kulturne pokrajine. V njihovem potencialu so osredotočene tiste pokrajinske sestavine, ki s svojimi raznovrstnimi učinki vplivajo na spremembe v pokrajini (Markeš 1998). Ker so kmetije najpogosteje v lasti družin (t. i. družinske kmetije), je po Hriberniku (1994a, 32) »... kmečko prebivalstvo edini del družbe, ki sam zagotavlja svojo socio-profesionalno reprodukcijo ...«. »... Nasledstvo na kmetiji je zato eden ključnih dejavnikov reproduktivne sposobnosti kmetije in s tem njenega dolgoročnega obstoja .... (Kovačič 1996, 82). Nanj naj bi vplivali številni dejavniki, »... zato se zdi koristno, da bi jih kompleksneje preučili..." (prav tam, 82).

Pri preučevanju vplivov smo se v raziskavi osredotočili na notranje dejavnike, ki so značilni za kmetijo oziroma izvirajo $z$ nje, med njimi pa na dejavnike socialnogeografske strukture kmetije - dejavnike poselitvene, posestne, demogeografske, proizvodne (ekonomske), tehnične in razvojno-inovativne strukture. V prispevku predstavljamo, kako ti dejavniki vplivajo na stanja in odločitve glede nasleditve na hribovskih kmetijah, in sicer kakšen vpliv ima vsak dejavnik posamično, neodvisno drug od drugega, in kakšen vpliv ima več dejavnikov hkrati.

Slika 1: Hribovske kmetije so pomembna prvina hribovske kulturne pokrajine.

Glej angleški del prispevka.

\section{Terminologija}

\subsection{Hribovska kmetija}

Da bi se prilagodili podatkom v virih, ki smo jih uporabili v raziskavi, smo hribovske kmetije opredelili na podlagi Robičeve $(1988 ; 1990)$ členitve območij z omejenimi dejavniki za kmetovanje, in sicer kot kmetije, ki ležijo v gorsko-višinskem območju, na več kot 600 metrih nadmorske višine, in tudi kot kmetije, ki ležijo pod 600 metri nadmorske višine, vendar imajo več kot $60 \%$ kmetijskih zemljišč v nagibu nad $35 \%$ - po Robičevi tipologiji t. i. strme kmetije.

\subsection{Stanje in odločitve glede nasleditve na kmetiji}

Stanje in odločitve glede nasleditve na kmetiji smo v raziskavi opredelili kot podpomenko termina nasledstvo na kmetiji, ki poleg tega hiponima vključuje še časovno opredelitev prenosa kmetije na naslednika oziroma čas predaje kmetije nasledniku (angleško timing of succession). Stanje glede nasleditve na kmetiji pomeni, ali je na kmetiji že oziroma ali bo kot naslednik določena/predvidena oseba, ki bo za gospodarjem zagotovo v celoti prevzela nadzor nad upravljanjem, vodenjem kmetije ter bo postala tudi gospodar in lastnik kmetije, pri tem pa ni nujno, da je ta oseba gospodarjev potomec (v raziskavi so nasledniki v 98,7\% gospodarjevi potomci) in da živi v istem gospodinjstvu kot gospodar, odločitev glede nasleditve na kmetiji pa pomeni, ali se je ta oseba že sama odločila, da bo gospodarja nasledila, ter ali se je tudi odločila, da bo nadaljevala s kmetovanjem po prevzemu kmetije ( $v$ raziskavi smo enačili termin prevzemništvo (prevzem) s terminom nasledstvo, čeprav pomeni po Kladniku (1999) prevzemništvo predajo kmetije v upravljanje, pri tem pa z nasledstvom ni nujno, da pride tudi do spremembe lastništva).

\section{Metodologija}

\subsection{Metode dela in opredelitev odvisne spremenljivke}

Vplive dejavnikov socialnogeografske strukture na stanja in odločitve glede nasleditve na hribovskih kmetijah smo ugotavljali s pomočjo modelov diskretne izbire (angleško discrete choice models) - izraz smo prevzeli po Greenu (2003), ki te modele imenuje tudi modeli kvalitativnega odziva (angleško qualitative response $(\mathrm{QR})$ models). Modeli sodijo med regresijske modele in v nasprotju s klasičnimi linearnimi regresijskimi 
modeli (izraz je povzet po Gujaratiju (1995)) omogočajo vpogled v kavzalne zveze med pojasnjeno, odvisno spremenljivko $\left(Y_{i}\right)$ in eno ali več pojasnjevalnimi, neodvisnimi spremenljivkami $\left(X_{1} \ldots X_{k}\right)$, tudi če ne poznamo zveznih, kvantitativnih vrednosti odvisne spremenljivke, temveč ločimo le končno število izidov, ki zavzemajo diskretne, kvalitativne vrednosti (Bajt in Štiblar 2002; Juvančič 2002, povzeto po Maddala 1999; Wooldridge 2002).

Ker je po Foxu (1997) za regresijske modele značilno, da lahko na podlagi sprejetega modela in ocen njegovih parametrov iz vrednosti pojasnjevalnih spremenljivk napovemo vrednost odvisne spremenljivke, omogočajo modeli diskretne izbire - kot verjetnostni modeli - napovedovanje verjetnosti odziva oziroma izbire (angleško forecasting response/choice probability) (Liao 1994; Wooldridge 2002). Greene (2003) pojasnjuje to z zapisom:

$\operatorname{Prob}(\operatorname{dogodek} j$ se zgodi $)=\operatorname{Prob}(Y=j)=P($ relevantni učinki, parametri $)$

Pri tem pomeni Prob $(Y=j)$ verjetnost, da se bo dogodek $j$ pri danih $X_{i}$ zgodil, dogodek (angleško event) pa posameznikovo izbiro med alternativami - izidi, ki jih zavzema odvisna spremenljivka $Y_{i}$.

V raziskavi smo se omejili na dva izida odvisne spremenljivke $Y_{i}$, in sicer:

$Y_{i}=1$ kmetijo bo prevzel naslednik, ki se bo na njej še naprej ukvarjal s kmetovanjem;

$Y_{i}=0$ na kmetiji ne bo prišlo do nasleditve oziroma kmetijo bo naslednik prevzel, vendar se ne bo ukvarjal s kmetovanjem.

Pri tem je izid dogodkov predviden oziroma načrtovan - načrtovana (predvidena) so torej stanja in odločitve glede nasleditve na kmetijah (angleško planned farm succession). Takšen pristop preučevanja imenujemo ex-ante (internet 1,2).

Kot izhodiščni metodološki pristop izvedbe modelov diskretne izbire smo izbrali probit model, imenovan tudi normit model (angleško probit/normit model). Ker zavzema odvisna spremenljivka dva izida, gre v tem primeru za t. i. probit modele binarne izbire (angleško binary-choice/response probit models, dichotomous choice probit models).

\subsection{Opredelitev pojasnjevalnih spremenljivk}

Dejavnike socialnogeografske strukture hribovskih kmetij, za katere smo predvideli, da vplivajo na stanja in odločitve glede nasleditve na hribovskih kmetijah v Sloveniji, smo izrazili na en način ali na več različnih načinov. Načine, s katerimi prikazujemo dejavnike socialnogeografske strukture kmetij, smo v probit modelih binarne izbire opredelili kot pojasnjevalne spremenljivke. Vsako pojasnjevalno spremenljivko smo šifrirali z ustrezno oznako oziroma s simbolom in predstavili ustrezna merila. Ker so pojasnjevalne spremenljivke kvalitativne ali pa kvantitativne in so zato podatki merjeni v različnih enotah, smo jih po zgledu drugih empiričnih analiz oziroma izračunov modelov diskretne izbire poskušali med seboj (in znotraj njih samih) čim bolj umeriti ter zato ustrezno modificirati ali transformirati. S tem smo izpolnili eno od zahtev pri izvedbi regresijske analize - zahteva po homoskedastičnosti, kar po B. Košmelj in ostalih (2001) pomeni, da mora biti v regresijskem modelu varianca slučajnih napak oziroma vplivov konstantna za vse opazovane vrednosti pojasnjevalnih spremenljivk, ki so vnaprej določene.

\subsection{Podatkovni vir in opredelitev ciljne skupine ter raziskovalnega vzorca}

Podatke za raziskavo smo pridobili z anketiranjem. V primerjavi s podatki, ki jih nudijo statistične službe, lahko namreč z anketiranjem dobimo podrobnejši vpogled v stanja in odločitve glede nasleditve na kmetijah ter v njihovo socialnogeografsko strukturo kmetij, hkrati pa lahko pridobimo pomembne podatke, ki jih statistične službe ne zajemajo. Anketiranje smo izvedli po pošti, junija 2005.

Da bi bila socialnogeografska struktura posameznih hribovskih kmetij med seboj čim primerljivejša, smo za raziskavo oblikovali homogeno ciljno skupino hribovskih kmetij, ki smo jo določili na podlagi naslednjih kriterijev:

- kmetija se je nahajala v alpski ali predalpski Sloveniji, pri čemer smo območje alpskih in predalpskih pokrajin Slovenije določili na podlagi Ilešičeve naravnogeografske regionalizacije iz leta 1972;

- poglavitna proizvodna usmeritev na kmetiji je bila živinoreja - reja pašne živine ali mešana živinoreja;

- starost gospodarja na kmetiji je bila 45 let ali več. 
Na podlagi vseh treh kriterijev in po izločitvi nekaterih kmetij brez podatkov o starosti gospodarjev smo za ciljno skupino opredelili 6801 hribovsko kmetijo.

Slika 2: V alpski in predalpski Sloveniji je 70 \% vseh slovenskih hribovskih kmetij (opredeljene po Robičevi tipologiji).

Glej angleški del prispevka.

Med hribovskimi kmetijami ciljne skupine je bilo za anketiranje na podlagi ažurnih podatkov Statističnega registra kmetijskih gospodarstev v Sloveniji leta 2005 naključno izbranih 3000 gospodarjev. Med vrnjenimi anketnimi vprašalniki smo iz nadaljnje empirične analize izključili vse tiste, ki niso bili izpolnjeni v celoti, tako da je končni raziskovalni vzorec obsegal 789 hribovskih kmetij oziroma 11,6\% vseh hribovskih kmetij, ki smo jih na podlagi kriterijev opredelili kot ciljno skupino.

\section{Rezultati in razprava}

\subsection{Vplivi posameznih dejavnikov socialnogeografske strukture hribovskih kmetij}

S probit modeli binarne izbire smo ugotavljali, kako vpliva na odvisno spremenljivko $Y_{i}$ vsaka od pojasnjevalnih spremenljivk $X_{i}$, s katerimi smo izrazili posamezne dejavnike socialnogeografske strukture kmetije. Ce smo jih izrazili z več pojasnjevalnimi spremenljivkami, sta v preglednici 1 za vsak dejavnik socialnogeografske strukture kmetij prikazana jakost in smer vpliva tiste pojasnjevalne spremenljivke $X_{i}$, za katero se je izkazalo, da ima na odvisno spremenljivko $Y_{i}$ največji vpliv - pri tem imen in opisov izbranih pojasnjevalnih spremenljivk nismo navajali. Jakost vplivov je določena na podlagi $t$-vrednosti, smer vpliva vsakega posameznega dejavnika pa se nanaša (če ni navedeno drugače) na ugodno (pozitivno) stanje in odločitve glede nasleditve na kmetiji ter je določena glede na povečanje vrednosti dejavnika, če je dejavnik kvantitativne narave, oziroma s pritrditvijo, če gre za dejavnik kvalitativne narave in sta mogoča odgovora da in ne. Vsi prikazani vplivi pojasnjevalnih spremenljivk $X_{i}$ na odvisno spremenljivko $Y_{i}$, ki so za posamezne dejavnike prikazani v preglednici 1 , so statistično značilni vsaj pri 90-odstotnem intervalu zaupanja.

Kot je razvidno iz preglednice 1, vplivajo med dejavniki socialnogeografske strukture hribovskih kmetij na stanja in odločitve glede nasleditve na njih vsi dejavniki poselitvene, posestne, demogeografske, proizvodne (ekonomske) in razvojno-inovativne strukture, za katere smo te vplive predvideli. Ne vplivajo le dejavniki tehnične strukture, kar potrjuje Kovačičevo (2001) ugotovitev, da so slovenske kmetije preveč mehanizirane in da predstavlja posedovanje kmetijske mehanizacije statusni simbol.

\subsection{Vplivi več dejavnikov socialnogeografske strukture hribovskih kmetij hkrati}

Nameravali smo sicer ugotavljati, kako na stanja in odločitve glede nasleditve na hribovskih kmetijah hkrati vpliva čim večje število dejavnikov socialnogeografske strukture, vendar so morali biti pri izvedbi probit modela binarne izbire, zato da bi bil ta kar najboljši, za njihovo vključitev izpolnjeni naslednji pogoji:

- Pojasnjevalna spremenljivka $X_{i}$, s katero smo določen dejavnik izrazili, je morala biti določena za vse kmetije.

- Jakost vpliva pojasnjevalne spremenljivke $X_{i}$, s katerimi smo izrazili določen dejavnik, je morala biti izrazita.

- Probit modeli binarne izbire, s katerimi smo ugotavljali vplive posameznih pojasnjevalnih spremenljivk na odvisno spremenljivko $Y$, so morali biti dovolj zanesljivi in dovolj natančno so se morali približati opazovanim vrednostim - imeti so torej morali visoko pojasnjevalno vrednost.

- Med pojasnjevalnimi spremenljivkami, ki so ustrezale zgornjim zahtevam, smo v nadaljnjem postopku izbire izločili tudi tiste, ki so izražale največjo kolinearnost z ostalimi. Gre za pojav, pri katerem so pojasnjevalne spremenljivke med seboj tesno povezane. Dejavniki med seboj namreč ne delujejo izolirano, ampak se spreminjajo bolj ali manj skupno, na medsebojno povezan način (Pfajfar 1998).

Če so bili dejavniki izraženi z več pojasnjevalnimi spremenljivkami, smo izločene spremenljivke nadomestili z drugimi, vendar s tistimi, s katerimi smo lahko še vedno dovolj natančno pojasnili izide odvisne spremenljivke $Y_{i}$. Če je bil dejavnik izražen le z eno pojasnjevalno spremenljivko, je bil, če je bila takšna pojasnjevalna spremenljivka izločena, izločen tudi dejavnik. 
Preglednica 1: Jakosti in smeri izračunanih vplivov socialnogeografskih dejavnikov na stanje in odločitve glede nasleditve na hribovskih kmetijah v Sloveniji.

socialnogeografski dejavnik jakost in smer vpliva

dejavniki poselitvene strukture kmetije

lega kmetije (časovna/prostorska oddaljenost kmetije in naravna lega kmetije) (jakost in smer vpliva

sta določena, če naravna lega kmetije ni ugodna)

percepcija o oddaljenosti (izoliranosti) kmetije (Jakost in smer vpliva sta določena, če gospodar meni,

da je kmetija zelo oddaljena od glavnih prometnih poti v dolini in najbližjih administrativnih središč)

dejavniki demogeografske strukture kmetije

število oseb na kmetiji

število otrok v gospodarjevi družini

število otrok moškega spola v gospodarjevi družini

število generacij, v katerem je kmetija v rokah gospodarjeve družine.

odločitev gospodarja, ali bi se še enkrat odločil, da bo prevzel kmetijo in na njej gospodaril, če bi imel to možnost.

starost gospodarja

spol gospodarja (jakost in smer vpliva sta določena, če je gospodar moškega spola)

gospodarjeva nasleditev predhodnega gospodarja

gospodarjev zakonski oziroma zunajzakonski stan

končana višja raven splošne izobrazbe gospodarja

formalna kmetijska izobrazba gospodarja

zaposlitev gospodarja in/ali njegovega partnerja zunaj kmetije

spol naslednika (jakost in smer vpliva sta določena, če je naslednik moškega spola)

sorodstveno razmerje naslednika do gospodarja (jakost in smer vpliva sta določena, če je naslednik gospodarjev sin)

naslednik živi na gospodarjevi kmetiji.

končana višja raven splošne izobrazbe naslednika oziroma predvidena višja raven splošne izobrazbe naslednika

ob zaključku njegovega trenutnega šolanja (jakost in smer vpliva sta določena, če je oziroma bo naslednikova

splošna izobrazba srednješolska, posebej (v oklepajih) pa, če je oziroma bo naslednikova izobrazba višja

oziroma visokošolska)

formalna kmetijska izobrazba naslednika

zaposlitev naslednika zunaj kmetije

obseg opravljenega dela na kmetiji

spremembe obsega opravljenega dela na kmetiji v zadnjih desetih letih/v prihodnje (jakost in smer vpliva sta določena, +++/++++

če se je obseg opravljenega dela na kmetiji v zadnjih desetih letih povečal oziroma če se bo povečal v prihodnje)

dejavniki posestne strukture kmetije

velikost kmetije

percepcija o velikosti kmetije (jakost in smer vpliva sta določena, če gospodar meni, da je njegova kmetija velika)

spremembe velikosti kmetije v zadnjih desetih letih/v prihodnje (jakost in smer vpliva sta določena, če se je in/ali

se bo povečala velikost kmetije, tj. obseg površin kmetijskih zemljišč v uporabi ali število živine)

površina kmetijskih zemljišč v lasti kmetije, ki niso v uporabi za kmetijsko proizvodnjo.

najemanje kmetijskih zemljišč na kmetiji/dajanje kmetijskih zemljišč v najem

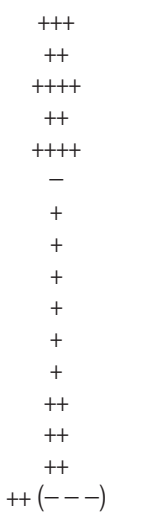

dejavniki proizvodne (ekonomske) strukture kmetije

tržnost živinorejske proizvodnje

intenzivnost živinoreje

količina letnega poseka lesa (etat)

vitalnost gozdnega potenciala (jakost in smer vpliva sta določena, če gospodar meni, da gozd ni izsekan)

ukvarjanje z dopolnilnimi dejavnostmi

višina letnega prihodka, ki izhaja iz virov na kmetiji.

zadovoljstvo z višino prihodkov, ki izvirajo iz virov na kmetiji.

delež, ki ga prinašajo k celotnemu letnemu prihodku na kmetiji viri s kmetije/viri zunaj kmetije.

delež, ki ga prinašajo $\mathrm{k}$ celotnemu letnemu prihodku na kmetiji subvencije.

vrste virov prihodkov, iz katerih so se v zadnjih desetih letih prihodki na kmetiji najbolj povečali/ki bodo

v prihodnje na kmetiji bolj prevladovali (jakost in smer vpliva sta določena, če so se v zadnjih desetih

letih prihodki na kmetiji najbolj povečali iz virov na kmetiji in če bodo ti prihodki v prihodnje na kmetiji

bolj prevladovali)

dejavniki tehnične strukture kmetije

opremljenost kmetij s stroji in z napravami

opremljanje kmetije s stroji in z napravami v prihodnje 
dejavniki razvojno-inovativne strukture kmetije

finančna sposobnost kmetije za vlaganje v nadaljnji razvoj

obremenitev kmetije za nadaljnji razvoj zaradi dolga najetih kreditov in drugih finančnih bremenitev ukvarjanje z ekološkim kmetovanjem

$++++$

$----$

$+$

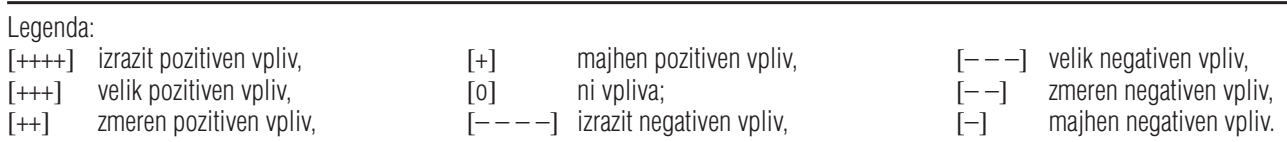

Postavljenim zahtevam so ustrezali naslednji dejavniki socialnogeografske strukture kmetije oziroma pojasnjevalne spremenljivke, $s$ katerimi smo jih izrazili (podrobnejši opisi pojasnjevalnih spremenljivk so v preglednici 2):

- gospodarjeva percepcija o odmaknjenosti (izoliranosti) - dejavnik poselitvene strukture kmetije, izražen s pojasnjevalno spremenljivko IZOL_LEG;

- odločitev gospodarja o prevzemu kmetije ob ponovni možnosti odločitve - dejavnik demogeografske strukture kmetije, izražen s pojasnjevalno spremenljivko G_ODLOC;

- število otrok moškega spola v gospodarjevi družini - dejavnik demogeografske strukture kmetije, izražen s pojasnjevalno spremenljivko OTRM_OTR;

- kmetijska zemljišča v lasti kmetije, ki niso v uporabi za kmetijsko proizvodnjo - dejavnik posestne strukture kmetije, izražen s pojasnjevalno spremenljivko KZZO_KZU (posredno je s tem dejavnikom izražena (dejanska) velikost kmetije (v model zaradi zmerne jakosti vpliva in kolinearnosti nismo vključili površine kmetijskih zemljišč v uporabi (KZU) oziroma števila živine (GVZ), ki sta najpomembnejša kazalnika, s katerima smo izrazili velikost kmetije). Čeprav bi bilo bolj smiselno vključiti v model pojasnjevalno spremenljivko, ki pomeni razmerje med skupno površino kmetijskih zemljišč, danih v najem, kmetijskih zemljišč v zaraščanju in neobdelanih kmetijskih zemljišč ter površino kmetijskih zemljišč v lasti kmetije (KZdNZO_KZL), smo zaradi kolinearnega značaja to pojasnjevalno spremenljivko zamenjali s pojasnjevalno spremenljivko KZZO_KZU;

- tržnost živinorejske proizvodnje - dejavnik proizvodne (ekonomske) strukture kmetije, izražen s pojasnjevalno spremenljivko ZIV_PROD;

- višina letnega prihodka, ki izhaja iz virov na kmetiji - dejavnik proizvodne (ekonomske) strukture kmetije, izražen s pojasnjevalno spremenljivko PR_EUR (ker na nobeni testni kmetiji niso vodili evidence spremenljivih in stalnih stroškov, smo se odločili, da bomo namesto podatkov o dohodkih z anketiranjem zbirali podatke o prihodkih);

- vrste virov prihodkov, ki bodo na kmetiji prevladovali v prihodnje - dejavnik proizvodne (ekonomske) strukture kmetije, izražen s pojasnjevalno spremenljivko PR_F_POV.

Preglednica 2: Oznake in opisi pojasnjevalnih spremenljivk, uporabljenih v izvedbi probit modela binarne izbire.

\begin{tabular}{|c|c|}
\hline Simbol & Opis \\
\hline IZOL_LEG & $\begin{array}{l}\text { Mnenje gospodarja o oddaljenosti, odmaknjenosti kmetije od najbližjih administrativnih središč in glavne ceste v dolini } \\
\text { (slamnata spremenljivka, to je spremenljivka, ki je prirejena vsaki vrednosti nominalne spremenljivke in dobi vrednost } 1 \text {, } \\
\text { če ima enota izbrano vrednost nominalne spremenljivke, in vrednost 0, če enota nima izbrane vrednosti nominalne spre- } \\
\text { menljivke, imenujemo slamnata (umetna) spremenljivka (angleško dummy variable) (B. Košmelj in ostali 2001) -1= da, } \\
0=\text { ne) }\end{array}$ \\
\hline G_ODLOC & $\begin{array}{l}\text { Odločitev gospodarja, ali bi se ponovno odločil, da bo prevzel kmetijo in na njej gospodaril, če bi imel to možnost } \\
\text { (slamnata spremenljivka }-1=\text { da, } 0=\text { ne). }\end{array}$ \\
\hline OTRM_OTR & Razmerje med številom otrok moškega spola in skupnim številom otrok v gospodarjevi družini (koeficient) \\
\hline KZZO_KZU & $\begin{array}{l}\text { Razmerje med skupno površino kmetijskih zemlijišč v zaraščanju in neobdelanih kmetijskih zemljišč ter površino } \\
\text { kmetijskih zemljišč v uporabi (koeficient) }\end{array}$ \\
\hline ZIV_PROD & Količina živinorejske proizvodnje za prodajo (modificirana vrednost - 1 = 100 odstotkov) \\
\hline PR_EVR & $\begin{array}{l}\text { Ocena višine letnega prihodka na kmetiji, ki izhaja iz virov na kmetiji (slamnata spremenljivka - } 0=\text { do } 2086,46 \text { evrov } \\
\text { (500.000 tolarjev), } 1 \text { = nad 2086,46 evrov (500.000 tolarjev)). }\end{array}$ \\
\hline PR_F_POV & $\begin{array}{l}\text { Vrsta virov prihodkov, ki bodo po mnenju gospodarja v prihodnje na kmetiji bolj prevladovali (slamnata spremenljivka - } \\
1 \text { = viri na kmetiji, } 0 \text { = viri zunaj kmetije). }\end{array}$ \\
\hline
\end{tabular}


Ker gre za modele diskretne izbire, ima izračunani model, ki je prikazan v preglednici 3, precej visoko napovedno moč - vrednosti odvisne spremenljivke $Y_{i}$, ki smo jih ocenili z modelom, se namreč z opazovanimi (dejanskimi) vrednostmi dokaj dobro ujemajo. Model napove pravilno 78,3\% vseh izidov odvisne spremenljivke $Y_{i}$, vrednost McFaddnovega $R^{2}$ oziroma LRI pa je 0,314 . Po Juvančiču (2002, po Huffmanu 1991) lahko že vrednosti LRI-ja nad 0,3 ocenimo kot visoke, smiselne rezultate pa naj bi dajali tudi modeli z nižjimi vrednostmi. Najmanjši vpliv ima dejavnik, opredeljen kot višina letnega prihodka, ki izhaja iz virov na kmetiji (PR_EUR). Ta dejavnik je tudi edini, ki je statistično značilen pri 90-odstotnem intervalu zaupanja, drugi so namreč značilni pri manj kot 5-odstotnem ali manj kot 1-odstotnem tveganju.

V preglednici 3 so izračunane tudi vrednosti mejnih učinkov. Vrednost pove, za koliko se spremeni vrednost odvisne spremenljivke $Y_{i}$, če se vrednost določene pojasnjevalne spremenljivke $X_{i}$ spremeni za eno enoto. Pri tem predvidevamo, da se vrednosti drugih pojasnjevalnih spremenljivk ne spreminjajo oziroma da so konstantne - t. i. predpostavka ceteris paribus (vsi ostali faktorji so nespremenjeni). Izračunane vrednosti mejnih učinkov temeljijo na povprečnih vrednostih pojasnjevalnih spremenljivk. Zato lahko govorimo o vplivu pojasnjevalnih spremenljivk na hipotetični/potencialni povprečni kmetiji (Gujarati 1995; Juvančič 2002; Wooldridge 2002; internet 3).

Preglednica 3: Rezultati izvedbe probit modela binarne izbire z več pojasnjevalnimi spremenljivkami.

\begin{tabular}{lcccr}
\hline pojasnjevalna spremenljivka & koeficient & t-vrednost & stopnja značilnosti & mejni učinki \\
\hline konstanta & $-0,537$ & $-3,192$ & 0,001 & $-0,109$ \\
IZOL_LEG & $-0,293$ & $-2,454$ & 0,014 & 0,149 \\
G_ODLOC & 0,395 & 3,057 & 0,002 & 0,015 \\
OTRM_OTR & 0,386 & 2,436 & 0,015 & $-0,004$ \\
KZZO_KZU & $-0,117$ & $-2,247$ & 0,025 & 0,004 \\
ZIV_PROD & 0,541 & 2,345 & 0,019 & 0,099 \\
PR_EUR & 0,261 & 1,672 & 0,094 & 0,130 \\
PR_F_POV & 0,345 & 2,648 & 0,008 & \\
\hline
\end{tabular}

število kmetij - N: 789

log-funkcija verjetja - $\log L:-395,00$

omejena $\left(\beta_{i}=0\right)$ log-funkcija verjetja - R log L: $-527,77$

test z razmerjem verjetij - LRT - (stopnja prostosti): $265,54(7)^{\star \star \star ~}$

McFaddnov psevdo- $R^{2}$ - oziroma indeks razmerja verjetij - LRI: 0,314

prilagojen McFaddnov psevdo- $R^{2}-: 0,307$

Akaikov informacijski kriterij - AIC: 1,046

delež pravilno napovedanih vseh izidov odvisne spremenljivke $Y$ - cenitev $R^{2}$ : 78,3\%

delež pravilno napovedanih izidov $Y_{i}=1\left(Y_{i}=0\right): 67,2 \%(85,4 \%)$

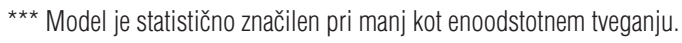

Vpliv gospodarjeve percepcije o legi hribovske kmetije (IZOL_LEG) na stanja in odločitve glede nasleditve na njej je negativen. Če gospodar hipotetične povprečne kmetije meni, da je kmetija oddaljena, odmaknjena od najbližjih administrativnih središč in glavne ceste $\mathrm{v}$ dolini, je verjetnost, da na njej do nasleditve ne bo prišlo ali da jo bo prevzel naslednik, ki se na njej ne bo ukvarjal s kmetovanjem, ob predpostavki ceteris paribus nižja za 10,9\%, kot pa če bi imel gospodar glede tega nasprotno mnenje. Gospodarjeva subjektivna percepcija o oddaljenosti (izoliranosti) kmetije ima torej pri pripravah in odločitvah določenega ali predvidenega naslednika za prevzem kmetije pomemben motivacijski učinek. Kot navaja Tietje (2004) po Neldertu in drugih (1981), se namreč usmerjenost staršev pogosto prenaša na otroke. Podrobnejša analiza rezultatov kaže, da je vpliv tega dejavnika povezan z boljšimi pogoji in možnostmi za zaposlitev zunaj kmetije (tudi v bolje plačanih službah), s tem pa tudi z možnostjo kombiniranja različnih dohodkov in zagotovitve življenjskega standarda, ki je primerljiv s standardom tistih, ki se ne ukvarjajo s kmetovanjem, kot tudi z drugo družbeno infrastrukturo, ki je dostopnejša in razvitejša. Do nasleditve in nadaljnjega kmetovanja bo namreč prišlo na več kot $85 \%$ kmetij, ki jih gospodarji ne zaznavajo kot prostorsko in časovno odmaknjene ter na katerih naj bi bili v prihodnje predvideni oziroma določeni nasledniki zaposleni tudi zunaj kmetij. To naj bi se zgodilo na okoli $43 \%$ kmetij, na katerih naj bi bili v prihodnje predvideni oziroma določeni nasledniki prav tako zaposleni zunaj kmetij, vendar gospodarji kmetije zaznavajo kot prostorsko in časovno izolirane. Kljub osebni motorizaciji se namreč z dnevno delovno migra- 
cijo zaradi večje oddaljenosti kmetij od delovnih mest v nekmetijskih dejavnostih povečajo fizične in tudi psihične obremenitve.

Slika 3: Na odmaknjenih hribovskih kmetijah je nasledstvo bolj ogroženo, kot na kmetijah, ki so bliže administrativnim središčem, različnim oblikam storitvenih dejavnosti in pomembnejšim prometnim potem.

Glej angleški del prispevka.

Pomemben motivacijski učinek za potencialne naslednike ima po Fasterdingu $(1995 ; 1999)$ in Tietju (2004) tudi gospodarjeva odločitev, da bi še enkrat prevzel kmetijo in na njej gospodaril, če bi imel to priložnost (G_ODLOC), saj izraža njegovo zadovoljstvo s poklicem, ki ga opravlja. Če bi se gospodar hipotetične povprečne kmetije ponovno odločil za prevzem, je ob predpostavki ceteris paribus verjetnost, da ga bo nasledil naslednik, ki se bo še naprej ukvarjal s kmetovanjem, 68,4-odstotna, če pa se za prevzem kmetije ne bi odločil, se verjetnost uresničitve dogodka $Y_{i}=1$ zniža za 14,8\%. Podrobnejša empirična analiza rezultatov še kaže, da je vpliv tega dejavnika na stanja in odločitve glede nasleditve na kmetiji večji, če živi naslednik ves čas na kmetiji, saj dobi v socializacijskem procesu natančen vpogled v delo gospodarja in kmečki način življenja nasploh, si pridobi neposredne izkušnje in medgeneracijsko posredovana znanja, hkrati pa se mu skozi pozitivno naravnanost gospodarja do vsega tega izoblikuje spoštljiv odnos, zlasti do zemlje kot primarnega vira za preživetje na kmetiji. Ravno tradicija je po Hriberniku (1993) še vedno izjemno močan dejavnik za vztrajanje pri kmetovanju tudi za mlajše generacije.

Slika 4: Zaradi predanosti tradiciji je zapuščanje kmetijstva manjše, kot bi lahko pričakovali glede na obroben položaj kmečkega poklica v slovenski družbi.

Glej angleški del prispevka.

Kot ugotavljata Kimhi in Nachlieli (2001) imajo pri nasleditvi gospodarjevi sinovi že po tradiciji prednost pred hčerami. Po Hriberniku (1994b) se namreč vedenjski vzorci pri prenosu kmetij na naslednike zelo dobro ohranjajo. To potrjuje tudi pozitiven vpliv števila otrok moškega spola v gospodarjevi družini (OTRM_OTR) na stanja in odločitve glede nasleditve. Če so na hipotetični povprečni kmetiji vsi gospodarjevi otroci moškega spola, je ob predpostavki ceteris paribus verjetnost, da bo kmetijo prevzel naslednik, ki se bo na njej še naprej ukvarjal s kmetovanjem, skoraj 70-odstotna. Če je na takšni kmetiji polovica gospodarjevih otrok moškega, polovica pa ženskega spola, je ob isti predpostavki verjetnost, da se bo zgodil dogodek $Y_{i}=1,62,9$-odstotna, če ima gospodar le otroke ženskega spola, pa 55,2-odstotna. Podrobnejša analiza kaže, da gospodarji za prevzem kmetije izberejo hčere običajno zato, ker nimajo moških potomcev - na skoraj $65 \%$ proučenih kmetij, na katerih so za prevzem kmetije izbrane hčere gospodarjev, ni moških potomcev. Hkrati so hčere za prevzem kmetije navadno le predvidene - takšnih je 84,6 \% izbranih naslednic - in niso določene zagotovo. Iz tega lahko sklepamo, da nekateri gospodarji še vedno upajo, da bodo lahko določili moškega naslednika. Takšen tradicionalni vzorec ravnanj in mišljenj ogroža obstoj kmetij - zavira namreč proces nasledstva in (pravočasen) prenos kmetij na naslednike, menimo namreč, da ni pomembno, da so nasledniki moškega spola.

Tržnost živinorejske proizvodnje (ZIV_PROD) je sicer dejavnik ekonomske strukture kmetije, vendar izraža tudi razvojno naravnanost. Pri tržni proizvodnji morajo namreč kmetje kmetijsko proizvodnjo prilagajati tržnim zahtevam in proizvajati produkte, za katere je na trgu povpraševanje in ki so primerne kakovosti. Ker se v takšnih razmerah po Vrišerju (1995) najbolj znajdejo dinamični in mlajši ljudje, smo sklepali, da je vzpodbudno za potencialnega naslednika, da se odloči za prevzem kmetije in na njej nadaljuje s kmetovanjem, kar potrjujejo rezultati modela. Če se na hipotetični povprečni kmetiji tržni delež živinorejske proizvodnje poveča za $1 \%$, se ob predpostavki ceteris paribus verjetnost, da bo kmetijo prevzel naslednik, ki bo na njej nadaljeval s kmetovanjem, poveča za $0,4 \%$. Če je tržni delež živinorejske proizvodnje 50-odstoten, znaša na takšni kmetiji verjetnost uresničitve dogodka $Y_{i}=1 \mathrm{ob}$ isti predpostavki $61,4 \%$, če pa je delež 100 -odstoten, pa $70,5 \%$. Če na hipotetični povprečni kmetiji produktov živinorejske proizvodnje ne prodajajo, je verjetnost, da bo kmetijo prevzel naslednik, ki bo na njej nadaljeval s kmetovanjem, ob predpostavki ceteris paribus 51,2-odstotna. Podrobnejši rezultati empirične analize še kažejo, da na kmetijah z nizko tržnostjo živinorejske proizvodnje zlasti starejši gospodarji pogosto vztrajajo pri kmetovanju in to pričakujejo tudi od svojih naslednikov - na proučevanih kmetijah je namreč skoraj 60 \% gospodarjev, ki so starejši od 65 let, že določilo ali predvidelo svoje naslednike, vendar se ti za prevzeme ne bodo odločili ali pa s kmetovanjem ne bodo nadaljevali. Mnogim, zlasti starejšim gospodarjem 
pomeni torej kmetovanje ohranjanje tradicije, način, smisel življenja - življenjski projekt - in ne kapitala, ki ga je treba nenehno oplajati, s kmetijo in z okoljem pa so čustveno povezani.

Slika 5: Ko prevzame kmetijo naslednik, se njen razvoj okrepi - mogoče je govoriti o vplivu naslednika (angleško successor effect) oziroma o vplivu nove krvi (angleško new blood effect); mladi gospodarji so zato po Blancu in Perrier-Cornetu (1993) gibalo posodabljanja kmetijskih struktur.

Glej angleški del prispevka.

Na stanja in odločitve glede nasleditve na kmetiji ima pozitiven vpliv tudi višina letnega prihodka, ki izhaja iz virov na kmetiji (PR_EVR). Če je na hipotetični povprečni kmetiji letni prihodek, ki izhaja iz virov na kmetiji, nižji od 2086,46 evrov oziroma pol milijona tolarjev (ker smo anketiranje izvajali pred uvedbo evra, je ocena višine letnega prihodka navedena tudi v tolarjih), znaša verjetnost, da bo gospodarja na kmetiji nasledil naslednik, ki bo tudi nadaljeval s kmetovanjem, ob predpostavki ceteris paribus skoraj $56 \%$, če pa je ta prihodek višji od omenjenega zneska, je verjetnost uresničitve dogodka $Y_{i}=1 \mathrm{ob}$ isti predpostavki skoraj 66-odstotna. Čeprav je vpliv tega dejavnika manj zanesljiv, pa podrobnejša empirična analize podatkov proučenih kmetij razkriva dodatna spoznanja o vplivih tega dejavnika. Če znaša letni prihodek, ki izhaja iz virov na kmetiji, do 4172,93 evrov oziroma milijon tolarjev, je delež kmetij, na katerih ne bo prišlo do nasleditve oziroma njihovi nasledniki po prevzemu ne bodo nadaljevali s kmetovanjem, precej višji (62-odstoten), kot pri višjih letnih prihodkih, ki izhajajo iz virov na kmetiji (21-odstoten). Na teh (prvoomenjenih) kmetijah večina gospodarjev in/ali njihovih partnerjev pridobiva prihodke iz virov zunaj kmetije in tudi skoraj vsi določeni ali predvideni nasledniki nameravajo biti v prihodnje zaposlenih zunaj kmetije. Od teh se jih več kot $60 \%$ za prevzem ne bo odločilo oziroma po predvidenem prevzemu na kmetijah ne bodo nadaljevali s kmetovanjem. Nasprotno bo na kmetijah, na katerih znaša po oceni izpraševancev letni prihodek, ki izhaja iz virov na kmetiji, do 12.518,78 evrov oziroma 3 milijone tolarjev, skoraj $85 \%$ določenih ali predvidenih naslednikov, ki nameravajo biti v prihodnje zaposleni zunaj kmetije, kmetije prevzelo in na njih nadaljevalo s kmetovanjem, torej bodo združevali prihodke iz virov na kmetiji in iz virov zunaj kmetije. Na teh kmetijah predstavljajo prihodki, ki izvirajo s kmetije, v povprečju več kot $44 \%$ celotnega letnega prihodka. Opisane značilnosti potrjujejo naša spoznanja, predstavljena pri razpravi o tržnosti živinorejske proizvodnje in ugotovitev A. Barbič $(1993,265)$, da "... mladi, ki ostajajo v kmetijstvu, počnejo to vse manj iz emocionalnih in vse bolj iz ekonomskih razlogov ...«; pa tudi Hribernikovo $(1996,28)$ ugotovitev, da »... bodo lahko preživele samo kmetije, ki bodo ustvarjale dovolj dohodka, kar pa pomeni iskanje možnosti zaslužka na bistveno širših osnovah ...«.

R. Gasson (1986) ugotavlja, da lahko zaposlitev zunaj kmetije, ki običajno največ prispeva k skupnemu deležu prihodkov iz virov zunaj kmetije, vpliva na večjo stabilnost in povišanje skupnega dohodka kmetije, s tem pa na donosnost in nadaljevanje kmetovanja, hkrati pa lahko pomeni prvi korak k prenehanju in opustitvi kmetovanja, zlasti če začnejo ti viri v skupnem letnem prihodku na kmetiji prevladovati. Glede vrste virov prihodkov, ki bodo v prihodnje na kmetiji prevladovali (PR_F_POV), se je izkazalo, da je vpliv tega dejavnika na stanja in odločitve glede nasleditve na kmetiji pozitiven, če bodo na kmetiji v prihodnje prevladovali prihodki iz virov na kmetiji. Pri tem znaša na hipotetični povprečni kmetiji verjetnost, da bo kmetijo prevzel naslednik, ki bo na njej tudi nadaljeval s kmetovanjem, ob predpostavki ceteris paribus 70,5\%, če pa bi naj prevladovali prihodki zunaj kmetije, je ta verjetnost na isti kmetiji in ob enaki predpostavki 57,5-odstotna oziroma $13 \%$ nižja. Rezultati potrjujejo ugotovitve o vlogi gospodarjevega zadovoljstva $\mathrm{z}$ delom na kmetiji. Sklepamo lahko namreč, da so potencialni nasledniki na kmetijah, na katerih so tesneje povezani z delom in življenjem na njih, bolj motivirani za prevzem kmetij in nadaljevanje kmetovanja na njih, kar potrjuje tudi ugotovitev, da bi se na kmetijah, na katerih prinašajo viri na kmetiji več kot polovico k celotnemu letnemu prihodku na kmetiji, skoraj $60 \%$ gospodarjev ponovno odločilo za njihov prevzem, na kmetijah, na katerih prinašajo več kot polovico k celotnemu letnemu prihodku na kmetiji viri zunaj kmetije, pa se jih večina za to ne bi odločila.

Vpliv kmetijskih zemljišč v lasti kmetije, ki niso v uporabi za kmetijsko proizvodnjo (KZZO_KZU), je na stanja in odločitve glede nasleditve pozitiven - verjetnost, da bo kmetijo prevzel naslednik, ki bo na njej tudi nadaljeval s kmetovanjem, se namreč zmanjšuje, če se na kmetiji v primerjavi s skupno površino kmetijskih zemljišč v uporabi povečuje skupna površina kmetijskih zemljišč, ki se zaraščajo oziroma niso obdelana. Če se na hipotetični povprečni kmetiji kmetijska zemljišča ne zaraščajo ali pa niso neobdelana - torej imajo na kmetiji v uporabi vsa svoja in morebitna najeta kmetijska zemljišča -, znaša ob predpostavki ceteris paribus verjetnost, da bo kmetijo prevzel naslednik, ki bo na njej tudi nadaljeval s kme- 
tovanjem, 65,5\%. Verjetnost se zniža za 4,5\%, če je na takšni kmetiji površina kmetijskih zemljišč v uporabi enaka površini kmetijskih zemljišč, ki se zaraščajo ali pa niso obdelana, če pa je na njej skupna površina kmetijskih zemljišč v zaraščanju ali pa niso obdelana trikrat večja kot skupna površina kmetijskih zemljišč v uporabi, se ob predpostavki ceteris paribus verjetnost uresničitve dogodka $Y_{i}=1$ zniža na 51,6\%.

Slika 6: Na kmetijah brez naslednikov se po gospodarjevi upokojitvi postopoma zmanjša število delovnih ur, površina kmetijskih zemljišč v uporabi in obseg kmetijske proizvodnje, vse manj pa vzdržujejo tudi stroje in strojno opremo ter objekte, ki pogosto ostajajo prazni kaže se zavedanje o bližajočem se koncu (angleško shadow of death effect).

Glej angleški del prispevka.

Rezultati tega dejavnika odpirajo pomembno dilemo, in sicer ali je raba kmetijskih zemljišč vzrok za stanje in odločitve glede nasleditve na kmetiji ali pa je posledica tega. Potter in Lobley (1992) jo interpretirata kot posledico, pri tem pa izhajata iz domneve, da pričakovanje, da bo do nasleditve prišlo oziroma da do nje ne bo prišlo, vpliva na obnašanja in odločitve gospodarjev. Avtorja v razpravah iz leta 1992, 1996a in 1996b govorita o t.i. vplivu nasledstva (angleško succession effect), pri čemer naj bi pričakovanje, da bo do nasleditve prišlo, motiviralo gospodarje, da sistematično vlagajo v razvoj kmetije, med drugim tudi optimalizirajo rabo kmetijskih zemljišč, medtem ko naj bi se na kmetijah, na katerih nasleditve ne pričakujejo, površina kmetijskih zemljišč v uporabi postopoma zmanjšala. Kot rešitev za razumevanje vzrokov in posledic so Stiglbauer in Weiss (2000), Kimhi in Nachlieli (2001) ter Glauben in ostali (2004) predlagali širši časovni okvir opazovanja, raziskovanje pa bi moralo biti po njihovem mnenju osredotočeno na spoznavanje življenjska cikla vsake kmetije posebej (angleško farm family life cycle).

\section{Sklep}

Raziskava je pokazala, da vplivajo na stanja in odločitve na hribovskih kmetijah dejavniki poselitvene, posestne, demogeografske, proizvodne (ekonomske) in razvojno-inovativne strukture, ne vplivajo pa dejavniki tehnične strukture. Posebej velik vpliv imajo dejavniki, ki izražajo, kako kmetijo, njeno strukturo, delo in življenje na njej dojemajo gospodarji, kar kaže, da imata socializacijski proces in spoštovanje tradicionalnih vrednot pri nasleditvah na hribovskih kmetijah še vedno zelo pomembno vlogo. Vendar pa sta veselje do dela in življenja na hribovskih kmetijah ter tradicija le predpogoj za odločitve potencialnih naslednikov, da bodo kmetije prevzeli in na njih kmetovali. Pogoj za to je primerna višina letnega prihodka, ki izhaja iz virov na kmetiji, in sposobnost kmetije za vlaganja v nadaljnji razvoj, velik vpliv pa ima tudi višina subvencij oziroma delež, ki ga te prinašajo k celotnemu letnemu prihodku na kmetiji. Če ta pogoj ni izpolnjen, stopijo v ospredje dejavniki, ki imajo na stanja in odločitve glede nasleditve na hribovskih kmetijah negativen vpliv (npr. večanje oddaljenosti kmetije od zaposlitvenih središč, v katerih bi lahko bili po prevzemu kmetij zaposleni določeni ali predvideni nasledniki, prevladovanje deleža prihodkov, ki izhajajo iz virov zunaj kmetije, naslednikova zaposlitev zunaj kmetije, višja oziroma visokošolska raven splošne (nekmetijske) izobrazbe naslednika). Ti dejavniki začnejo postopoma prevladovati, pri tem pa lahko začne vztrajanje pri tradicionalnih vzorcih ravnanj in razmišljanj ogrožati nadaljnji razvoj ter obstoj kmetij. Pomembno je tudi spoznanje, da je vsaka kmetija edinstvena, zato je tudi proces nasledstva na njej svojevrsten. Za razumevanje vzročno-posledičnih odnosov pri nasleditvah na hribovskih kmetijah bi se nadaljnja raziskovanja morala osredotočiti na spoznavanja življenjskega cikla vsake kmetije posebej.

\section{Literatura}

Glej angleški del prispevka. 
